Article

\title{
Exploring the Antecedents of Cruisers' Destination Loyalty: Cognitive Destination Image and Cruisers' Satisfaction
}

\author{
María Dolores Benítez-Márquez ${ }^{1, *(\mathbb{D}}$, Guillermo Bermúdez-González ${ }^{2}$ (D) Eva María Sánchez-Teba ${ }^{3}(\mathbb{D}$ \\ and Elena Cruz-Ruiz ${ }^{2}$ (D) \\ 1 Department of Applied Economics (Statistics and Econometrics), Faculty of Economics and Business, \\ University of Malaga, 29070 Malaga, Spain \\ 2 Department of Business Management, Faculty of Commerce and Management, University of Malaga, \\ 29071 Malaga, Spain; gjbermudez@uma.es (G.B.-G.); ecruz@uma.es (E.C.-R.) \\ 3 Department of Business Management, Faculty of Economics and Business, University of Malaga, \\ 29070 Malaga, Spain; emsanchezteba@uma.es \\ * Correspondence: bemarlo@uma.es
}

check for updates

Citation: Benítez-Márquez, M.D.; Bermúdez-González, G.; Sánchez-Teba, E.M.; Cruz-Ruiz, E. Exploring the Antecedents of Cruisers' Destination Loyalty: Cognitive Destination Image and Cruisers' Satisfaction. Mathematics 2021, 9, 1218. https://doi.org/ $10.3390 /$ math 9111218

Academic Editor: María del

Carmen Valls Martínez

Received: 1 April 2021

Accepted: 19 May 2021

Published: 27 May 2021

Publisher's Note: MDPI stays neutral with regard to jurisdictional claims in published maps and institutional affiliations.

Copyright: (c) 2021 by the authors. Licensee MDPI, Basel, Switzerland. This article is an open access article distributed under the terms and conditions of the Creative Commons Attribution (CC BY) license (https:/ / creativecommons.org/licenses/by/ $4.0 /)$.

\begin{abstract}
This study is one of the few of its kind that explores the individual impact of each of the cognitive attributes of a tourist destination's image on cruisers' destination loyalty and overall satisfaction. It also analyzes the mediating role of satisfaction between each of the attributes and loyalty. Variance-based structural equation modeling (PLS-SEM) was used for this analysis, based on a survey of 457 cruisers visiting the city of Malaga. The results confirm that three of the five attributes, the destination's environment image, the perceived value image of services and the accessibility image have a direct influence on cruisers' overall satisfaction, where environment image has the most significant impact. Moreover, the results support the mediating role of satisfaction in certain cases. There is total mediation between perceived value and loyalty, as well as between accessibility image and loyalty while there is only partial complementary mediation between environment image and loyalty. The confirmation that overall satisfaction influences loyalty enables management organizations to develop more efficient loyalty strategies for their respective destinations.
\end{abstract}

Keywords: cognitive destination image; cruise; satisfaction; loyalty; behavioral intention; structural equation modeling; PLS-SEM

\section{Introduction}

The relationship between satisfaction and the success of organizations has historically been considered to be a business reality, a fact that has been validated by various studies [1,2]. However, since the end of the 20th century, various authors have criticized this model in studies that demonstrate a high customer attrition rate despite having high rates of satisfaction [3-5], calling for a shift in the paradigm where loyalty becomes the new strategic objective for business success through customer retention.

The tourism sector is also susceptible to this paradigm shift. Both public and private institutions, in addition to academics, are growing increasingly interested in learning about the factors that influence loyalty to a tourist destination [6,7] and, consequently, the intention to revisit the destination and recommend it to other travelers.

Loyalty has been considered by different perspectives: attitudinal loyalty, behavioral loyalty and composite loyalty, as well as, the integration of attitudinal and behavioral [8]. Composite loyalty is often operationalized as behavioral intention which includes revisit intention and intention to recommend $[9,10]$. From now onwards, we use the term loyalty to refer to composite loyalty and we will use, alternatively, both terms-loyalty and behavioral intention-as synonyms.

Recent studies have established that destination loyalty, or behavioral intention, is the cornerstone of a tourist destination's brand equity and a determining factor in its competi- 
tiveness [11]. Within this context, numerous studies have confirmed that satisfaction with the travel experience [12-15] and destination image [16-18] are antecedents of loyalty and, therefore, the desire to return to a destination and recommend it to others. There is also discussion about the magnitude and direction of the relationships between the different components of destination image (both cognitive and affective) and tourist loyalty $[8,19,20]$.

However, there is very little information about the antecedents of tourists' destination loyalty in the scientific literature, especially considering that the cruise tourism sector is so important, although there are more studies that analyze the influence of image and/or cruisers' satisfaction on loyalty to the cruise line or their experience on board the ship [21-24] than the tourist destination itself [25-27]. There is also a lack of research regarding the relationship between the elements and attributes associated with destination image and the satisfaction and behavioral intention of travelers in general and cruisers in particular.

Considering the lack of empirical research that can explain these relationships, this article analyzes the antecedents of cruisers' loyalty to the tourist destination they are visiting and, specifically, the predictive power of the cognitive attributes of the tourist destination image on overall satisfaction and the influence of both on the behavioral intention of the cruisers visiting the city of Malaga (Spain).

Therefore, one key contribution of this article is to study, in the specific field of cruise tourism, the relationship between cognitive image and cruise passenger satisfaction and loyalty to the destination. Likewise, to the best of our knowledge, this is a novelty in which the attributes of the cognitive image of the destination are divided into five dimensions and their direct and indirect influence on satisfaction and loyalty are analyzed in the cruise tourism sector.

According to data from the Port Authority of Malaga [28] a total of 477,001 cruisers arrived at the Port of Malaga in 2019 on 288 ships, making it the second largest port in continental Spain in terms of visitors, after Barcelona. It is estimated that $11 \%$ of the tourists that visit Spain do so via cruise ships, generating a total revenue of 1.255 billion euros [29]. Following the United Nations World Tourism Organization [30], cruise travel has grown nearly 7\%, for a total of 28.5 million travelers. Cruises in the Mediterranean have increased by $8 \%$, for a total of over 4 million cruisers. These data justify the interest in studying a sector as important as cruise tourism and a destination as established as the city of Malaga (capital of the Costa del Sol).

In this study, destination loyalty is considered to be a dependent variable of variancebased structural equation modeling using partial least squares (PLS-SEM), while the different attributes of tourist destination cognitive image and overall satisfaction with the destination are predictor variables.

This article is organized in five sections, including the introduction. The second section offers a literature review regarding the perception of cruise passengers towards tourism, as well as the theoretical bases of the study and the relationship between image, satisfaction and loyalty. The third section includes the methodology and the data collected from the survey give to cruise passengers. The fourth section presents the results and the fifth section includes a discussion about these results, in addition to conclusions, limitations and proposed future lines of research.

\section{Literature Review and Hypotheses}

\subsection{Attributes of the Cognitive Image of a Tourist Destination}

Although the first generic studies about the importance of perceived image on human behavior were conducted in the 1950s [31,32], it was towards the end of the 20th century when researchers began to consider image as a determining factor in the individual perception of travelers and, consequently, in understanding their behavior and the tourist destination selection process [33-35].

Accordingly, measuring the image of a tourist destination [35-38], analyzing the changes in perception before, during and after the visit [39,40], determining the factors that influence image [41,42] and understanding the elements that compose said image [43-46], 
have been addressed by academics in numerous scientific articles. In the area of marketing, Hallmann et al. [47] demonstrated that the purchase decision process is simplified when the perception of a product or service is favorable and, therefore, their analysis is an effective marketing strategy, which plays a decisive role in the communication and commercialization of a destination as a tourism product.

There is a general consensus in the academic community that destination image is a multidimensional concept with at least two components: affective and cognitive [19,48], although some authors add a conative component as well [49,50].

The affective image of a destination refers to the emotions that individuals associate with the place they are visiting [41,43,51-54], while the cognitive image of a destination is related to the beliefs and knowledge a tourist has about the destination and arises from their assessment of the perceived attributes [43,55-57].

Conative image, on the other hand, is associated with an individual's behavior or true intention towards the destination, such as revisiting it, recommending it $[56,58,59]$ or speaking positively about it [60]. Within this context, there are numerous researchers that associate it with destination loyalty or behavioral intention more than a component of destination image $[12,19,55,61]$.

These dimensions can be studied separately in order to better understand their complexity as a whole [49,62-64], as the authors have done in this paper, focusing on the attributes of cognitive destination image for cruisers.

So, present research focuses on cognitive destination image. This election is justified, as indicated by Walmsley and Young [65], because the cognitive component is more descriptive, measurable and observable than the affective component and provides more specific information about the destination that is easier to interpret [42]. There are numerous empirical studies that analyze and support the cognitive component of destination image for its ability to characterize a destination, e.g., $[43,66]$, and, also, using a multi-attribute approach [67-70].

The attributes that are most highly referenced by academics include environment image (the main indicators of which include the natural environment and climate) [71], green management [72,73], the atmosphere [74] and the singularity of cultural image and cultural heritage [56]. Other noteworthy attributes include infrastructure image, which mainly refers to available restaurant, shopping and accommodation services [43]. Similarly, various authors consider other attributes to be integral to cognitive destination image, such as attractions and entertainment image [12], accessibility image [75] and the perceived value image of services [76].

For the purposes of this study, we consider cognitive destination image from a multi attribute perspective, consisting of the aforementioned attributes we have adapted from Chi and Qu [12]: environment image, available infrastructure image, attractions and entertainment image, accessibility image and the perceived value image of services.

\subsection{Impact of the Attributes of Cognitive Destination Image on Cruisers' Satisfaction and Loyalty}

Numerous researchers have studied the influence of cognitive destination image on travelers' satisfaction [19,77-81], loyalty and behavioral intention [55,82] or on both concepts [12,16,17,83-87].

The correlation of destination image with satisfaction and loyalty has been studied to a lesser degree in the cruise tourism sector $[22,27,88,89]$. However, there are very few scientific studies that specifically analyze the relationship between cognitive image and these constructs, which can be considered in certain cases to be either a relevant, positive relationship $[27,90]$ or of little significance [85].

Therefore, although there is research on the influence of a destination's overall image and some research on cognitive image, there are very few studies on the relationship of each of the integral attributes of the destination's cognitive image with travelers' loyalty and satisfaction and more so in the area of cruise tourism. 


\subsubsection{Impact of Environment Image}

Various authors have analyzed the influence of environment image on travelers' satisfaction and loyalty. Jin et al. [91] define environment image as the relevant cognitive experience that influences the perception of a place when an individual is traveling to a specific destination. This perception affects their satisfaction and loyalty, especially in relation to their intention to revisit or recommend the destination.

Several studies $[79,92,93]$ have demonstrated a positive influence of the destination's environment image on tourists' satisfaction. Research has also been conducted on its influence on the behavioral intention model associated with loyalty [94]. Ortegón-Cortázar and Royo-Vela [95] also demonstrated the indirect and positive influence of natural environment on behavioral intention through satisfaction.

Among the specific literature about cruise tourism, authors such as Sanz-Blas and Carvajal-Trujillo [96] or Toudert and Bringas-Rábago [27] have confirmed the direct relationship of the environment image construct with satisfaction on the one hand and destination loyalty on the other. Others, however, DiPietro and Peterson [25] or Silvestre et al. [26] have focused their research on the relationship of the latent variable (environment image) with the cruiser's intention to return to the destination and recommend it.

Keeping in mind all of these considerations, we postulate the following hypotheses:

H1. Environment image has a direct, positive, influence on satisfaction.

H2. Environment image has a direct, positive, influence on loyalty.

H3. Satisfaction mediates between environment image and loyalty.

\subsubsection{Impact of Attractions and Entertainment Image}

As indicated by Albaity and Melhem [16], the attractions and entertainment image is a determining factor in the selection of a tourist destination. This perception also affects the general image of the destination, influencing other attributes and the decision-making process [97]. Other authors such as Zhang [98] include this attribute in leisure experience.

The influence of a destination's attractions and entertainment on travelers' satisfaction has been adequately studied in the scientific literature $[93,99]$. Similarly, the influence of this cognitive attribute on loyalty and behavioral intention has also been considered in multiple studies $[92,100,101]$.

In the cruise tourism sector, from the best of our knowledge, no one has studied the direct influence of attractions and entertainment image on cruisers' satisfaction or their future behavioral intention (as loyalty) in regard to the destination. However, there are studies that measure indirectly how attractions and entertainment can influence satisfaction such as Sanz-Blas and Carvajal-Trujillo [96] and Sanz-Blas et al. [89] include this attribute in a second order construct (destination image) and demonstrate its influence on cruisers' satisfaction.

Furthermore, the items related to attractions and entertainment image (which the authors have included in the dimension entitled tourism resources) have a low degree of relevance in relation to the destination image construct as compared to other attributes such as infrastructure image and environment image. However, Toudert and BringasRábago [27] consider that this construct has the greatest influence on cruisers' satisfaction for the destination Baja California.

We have also found few studies that indirectly analyze the influence of attractions and entertainment on destination loyalty (revisiting and recommending it). Thus, Silvestre et al. [26] have included what we call attractions and entertainment in a construct entitled satisfaction with the city and the visit, concluding that there is no significant direct relationship between this construct (which includes attractions and entertainment image) and cruisers' destination loyalty. Additionally, Lee [102] tested a significant positive relation between leisure experience and behavioral intention through destination perceived value.

Therefore, we have developed the following hypotheses based on the literature review: 
H4. Attractions and entertainment image has a direct, positive, influence on satisfaction.

H5. Attractions and entertainment image has a direct, positive, influence on loyalty.

H6. Satisfaction mediates the relationship between attractions and entertainment image and loyalty.

\subsubsection{Impact of Infrastructure Image}

Accommodations and restaurant services consist of a series of products and services, making it a much more complex task to present an image that meets travelers' expectations [103]. It is important to study the role of this infrastructure on destination image since general satisfaction in the tourism sector is strongly related to infrastructure image, specifically restaurant and accommodation services, among other variables [104]. A study by Simarmata et al. [105] highlights that tourism infrastructure image (travel agencies, accommodations and restaurants) has a significant influence on visitors' satisfaction. In the area of cruise tourism, various authors have confirmed that infrastructure is a decisive component of destination image [41,96]. However, Puh [80] does not consider infrastructure to play a decisive role in the formation of said image and, consequently, on satisfaction.

In regard to loyalty, various studies have concluded that if the image of the services and infrastructure available at a destination are positive, this could stimulate word-ofmouth recommendations, as well as travelers choosing to revisit the same destination in the future $[12,14,106]$. Similarly, regarding cruise tourism, a positive experience at the port of call has a decisive influence on travelers' behavioral intention to revisit a specific port and even to recommend visiting that destination to people they know [26]. Furthermore, Nasir et al. [107] studied the indirect relationship between the infrastructure and loyalty to destination

Consequently, based on the relevant literature, we propose the following hypotheses:

H7. Infrastructure and services image has a direct, positive, influence on satisfaction.

H8. Infrastructure and services image has a direct, positive, influence on loyalty.

H9. Satisfaction mediates between infrastructure and service image, and loyalty.

\subsubsection{Impact of Perceived Value Image}

Perceived value is defined by Zeithaml [108] as a consumer's overall assessment regarding the utility of a product or service, which is based on their perception of what is received and what is given. According to Lovelock [109], this concept is the balance between the perceived benefits and perceived costs.

Various studies have highlighted the importance of the relationship of the qualityvalue-loyalty chain $[76,110]$ specifically determined that quality is an antecedent of perceived value, while satisfaction is a consequence of perceived value, which results in an attitude of loyalty. Many authors have studied this relationship in the tourism sector [15,111-118]. In particular, a tourist's perceived value of the quality of the trip is a construct that is directly related to their satisfaction with said trip $[119,120]$. In turn, satisfaction has an indirect relationship with loyalty $[10,121]$. Specifically, in the area of cruise tourism, various authors have studied the price-quality relationship (a component of our perceived value attribute) and its positive effect on satisfaction [26,88,122].

Similarly, other authors have demonstrated that perceived value in relation to loyalty has a positive impact on a tourist's decision to return to a destination $[114,123]$. According to studies by various authors, this relationship is also true in the area of cruise tourism $[124,125]$.

Based on the aforementioned literature, we propose the following hypotheses:

H10. Perceived value image has a direct, positive, influence on satisfaction.

H11. Perceived value image has a direct, positive, influence on destination loyalty.

H12. Satisfaction mediates between perceived value and loyalty. 


\subsubsection{Impact of Accessibility Image}

The accessibility of a destination is one of the attributes of cognitive image that determines tourists' satisfaction [79]. Many authors have considered the accessibility construct: making sure that the area has the appropriate signage [126], the importance of the location's accessibility factors for disabled tourists [127] and access to tourism information [128]. In regard to cruisers, the urban environment has a significant influence [27] on having a positive experience at the destination, which in turn influences the development of a positive image of the location visited. Furthermore, Wisker et al. [129] studied the indirect relationship between the accessibility and loyalty to destination.

Regarding its relationship with loyalty, tourists that positively value a destination's accessibility are more prone to travel during the off-season, which can help reduce the effects of seasonality as they have more time and, on average, stay longer at the destination, thereby spending more than average at said location. Furthermore, the more satisfied visitors are with the tourism available at a destination, the more loyal they are to said destination [75].

Consequently, we propose the following hypotheses:

H13. Accessibility image has a direct, positive, influence on satisfaction.

H14. Accessibility image has a direct, positive, influence on destination loyalty.

H15. Satisfaction mediates between accessibility image and loyalty.

\subsection{Influence of Tourists' Satisfaction on Destination Loyalty}

The relationship between satisfaction with the travel experience and destination loyalty or behavioral intention has been amply studied in the scientific literature. Satisfaction is considered to be both an antecedent [13-15] and a mediator of image and loyalty $[12,83,86,130]$.

In addition to a rational preference, satisfaction often leads to an emotional relationship, which creates greater customer loyalty [131]. Loyalty also makes customers more prone to recommend a tourist service to the people they know [132]. In parallel, in the cruise tourism sector, cruisers' satisfaction is also a determining factor of loyalty. Silvestre et al. [26] determined that satisfaction with the city and the visit is a more decisive determining factor than satisfaction with establishments and services. Similarly, Brida and Coletti [133] concluded that the probability of cruise tourists revisiting a destination depends on their satisfaction with their experience at the destination. Along these lines, other researchers have concluded that general satisfaction has a positive influence on cruisers' loyalty, which is understood as their intention to return to the destination and recommend it $[96,134]$. Similarly, according to Satta et al. [135], there is a positive relationship between satisfaction with the destination and cruisers' word-of-mouth recommendations. Finally, Toudert and Bringas-Rábago [27] and Albaity and Melhem [16] have analyzed the influence of satisfaction as a mediator between a cruise's image and destination loyalty.

Therefore, in accordance with the points made above, we propose the following hypothesis:

H16. Overall satisfaction has a direct, positive, significant influence on destination loyalty.

\section{Data Collection and Methods}

\subsection{Description of the Study Location: Malaga (Costa del Sol, Spain)}

Malaga, the capital of the Costa del Sol (Andalusia, Spain) is a coastal city in the Mediterranean and tourism is the most important component of its economy. In 2019, the city had a population of 574,654 residents and received over 1.4 million tourists, making it the third largest tourist destination in Spain in terms of the annual number of visitors [136] and the second largest in terms of the number of cruisers in continental Spain, after Barcelona, with a total of 477,001 cruise passengers [29]. Consequently, Malaga was chosen for this study due to its importance in Spain's cruise tourism sector (Figure 1). 


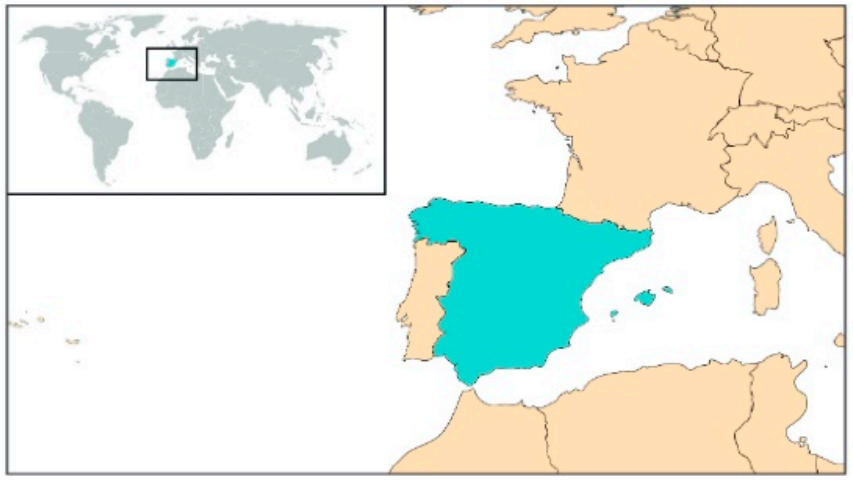

(a)

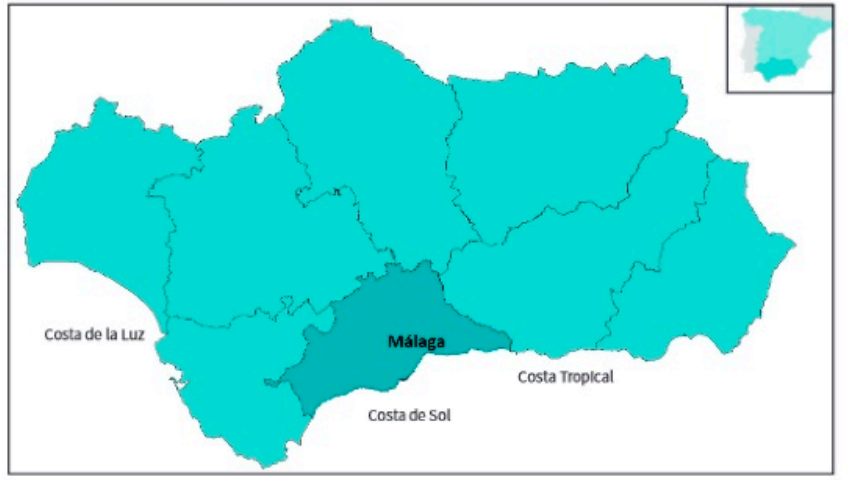

(b)

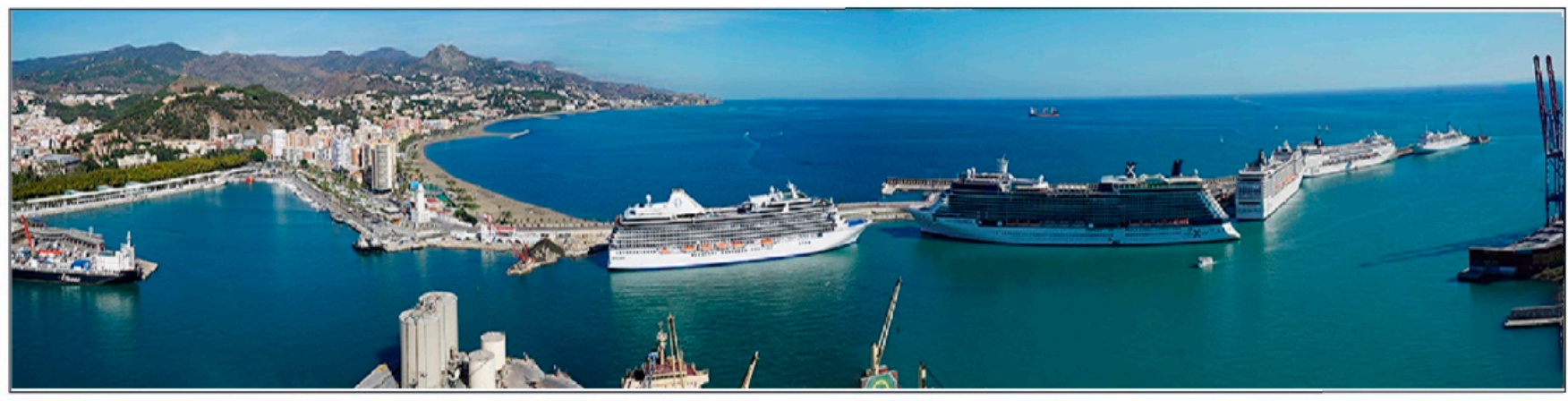

(c)

Figure 1. Location of Malaga (Andalusia, Spain) and photo of Port of Malaga. Source: Map (a) and map (b) from [137], map (b) own modification and photo (c) [138].

\subsection{Sample, Data Collection and Construct Measures}

A cross-sectional study was conducted with a random sample using raw data from a survey in which cruise tourists are the unit of analysis. The data were collected throughout the year 2019 from cruisers traveling on different ships. The questionnaire was handed out in person, in hard copy format, as passengers were boarding the ship after returning from visiting the city. Once the data were collected, a total of 457 valid surveys were considered (from a total of 470 collected) and there were no missing values (Table 1). The survey is included in the Supplementary Material.

Table 1. Descriptive sociodemographic.

\begin{tabular}{cccccccc}
\hline \multicolumn{2}{c}{ Range } & Frequency & Percentage & Indicator & Category & Frequency & Percentage \\
\hline \multirow{2}{*}{ Age } & $18-30$ & 74 & 16.2 & Sex & Man & 217 & 47.5 \\
& $30-40$ & 51 & 11.2 & & Woman & 240 & 52.5 \\
& $40-50$ & 59 & 12.9 & & Total & 457 & 100.0 \\
& $50-60$ & 86 & 18.8 & N (sample size) & & & 100.0 \\
& $60-70$ & 129 & 28.2 & Valid & 457 & 0 \\
\hline
\end{tabular}

Source: Own elaboration from SPSS.

A 7-point Likert scale was used to evaluate the degree of agreement or disagreement with each statement ( $1=$ strongly disagree, $4=$ neutral, $7=$ strongly agree). The frequency and percentage of the respondents' ages and genders were included in the survey (see Table 1). At a 5\% level of significance and a statistical power of $80 \%$, with a maximum of 3 arrows pointing at a construct in the structural model and a minimum of $10 \%$ explained variance, according to this author, the minimum sample size is 300 [139] and, therefore, the 
sample more than fulfills this requirement. Table 2 shows the items included in the survey and their descriptive measures.

Table 2. Survey items about the city of Malaga (Andalusia, Spain).

\begin{tabular}{|c|c|c|c|c|c|c|c|c|}
\hline Indicators or Items & No. & Mean & Me & Min & Max & $\begin{array}{l}\text { Standard } \\
\text { Deviation }\end{array}$ & $\begin{array}{l}\text { Excess } \\
\text { Kurtosis }\end{array}$ & Skewness \\
\hline \multicolumn{9}{|l|}{ 1st construct: 1 . Environment } \\
\hline 1.1. Pleasant weather & 1 & 5.796 & 6 & 1 & 7 & 1.43 & 1.394 & -1.279 \\
\hline 1.2. Clean and tidy environment & 2 & 6.039 & 6 & 2 & 7 & 1.19 & 0.513 & -1.139 \\
\hline 1.3. Friendly and helpful local people & 3 & 5.937 & 6 & 1 & 7 & 1.194 & 0.943 & -1.101 \\
\hline 1.4. Safe and secure environment & 4 & 5.921 & 6 & 1 & 7 & 1.237 & 0.597 & -1.082 \\
\hline 1.5. Picturesque views & 5 & 6.035 & 7 & 1 & 7 & 1.185 & 0.189 & -1.018 \\
\hline \multicolumn{9}{|l|}{ 2nd construct: 2 . Attractions and entertainment } \\
\hline 2.1. Wide arrays of shows/exhibitions & 6 & 4.521 & 4 & 1 & 7 & 1.075 & 0.903 & 1.33 \\
\hline 2.2. Wide variety of entertainment & 7 & 4.519 & 4 & 2 & 7 & 1.059 & 0.885 & 1.345 \\
\hline 2.3. Tempting cultural events & 8 & 4.593 & 4 & 1 & 7 & 1.15 & 0.27 & 1.118 \\
\hline \multicolumn{9}{|l|}{ 3rd construct: 3 . Infrastructure and service } \\
\hline 3.1. Wide selection of restaurants/cuisine & 9 & 5.508 & 6 & 1 & 7 & 1.312 & -0.837 & -0.373 \\
\hline 3.2. Wide variety of shopping options & 10 & 5.597 & 6 & 1 & 7 & 1.274 & -0.391 & -0.537 \\
\hline 3.3. Wide choice of accommodations & 11 & 4.648 & 4 & 1 & 7 & 1.144 & 0.185 & 0.949 \\
\hline \multicolumn{8}{|l|}{4 th construct: 4 . Perceived value } & -0.079 \\
\hline 4.1. Good value for money & 13 & 5.263 & 5 & 1 & 7 & 1.325 & -0.694 & -0.265 \\
\hline 4.2. Reasonable price for attractions and activities & 14 & 5.026 & 5 & 1 & 7 & 1.323 & -0.793 & 0.168 \\
\hline 4.3. Good bargain shopping & 15 & 4.814 & 4 & 1 & 7 & 1.429 & -0.399 & 0.046 \\
\hline 4.4. Appropriate signposting & 16 & 5.449 & 6 & 1 & 7 & 1.382 & -0.523 & -0.501 \\
\hline \multicolumn{9}{|l|}{ 5th construct:5. Accessibility } \\
\hline 5.1. Easy access to city center & 17 & 5.917 & 6 & 1 & 7 & 1.265 & 1.022 & -1.146 \\
\hline 5.2. Disabled access & 18 & 4.814 & 4 & 1 & 7 & 1.261 & -0.382 & 0.498 \\
\hline \multicolumn{8}{|l|}{ 6th construct: 6 . Satisfaction with destination } & -0.552 \\
\hline 6.1. Overall Satisfaction (1 item) & 20 & 6.088 & 6 & 3 & 7 & 1.008 & 0.514 & -1.05 \\
\hline \multicolumn{9}{|l|}{ 7th construct: 7 . Loyalty with destination } \\
\hline 7.1. Intention to revisit it & 21 & 5.737 & 6 & 1 & 7 & 1.415 & 1.024 & -1.171 \\
\hline 7.2. Intention to recommend & 22 & 6.057 & 6 & 1 & 7 & 1.142 & 1.696 & -1.304 \\
\hline
\end{tabular}

Note: $N=$ Total participants $=457 ; \mathrm{Me}=$ Median. Source: Own elaboration from [140].

Infrastructure, perceived value and accessibility have been validated as measurement instruments by $\mathrm{Chi}$ and $\mathrm{Qu}$ [12]. Environment and, also, attractions and entertainment has been validated by means of individual factor analysis for each construct with SPSS software prior to import the database to the software SmartPLS. Different studies have used the overall satisfaction as measure, e.g., $[12,79,141,142]$. In addition, as we mentioned in the introduction section, loyalty can be measured through the variables used to measure behavioral intention, the return intention and the recommendations to friends and relatives [8-10,12,61,80,143-146].

\subsection{Data Analysis}

In our case, the descriptive analysis of the items in the measurement scales confirmed that the data does not follow a normal distribution based on skewness as the data exceeds the recommended thresholds of \pm 1 [147].

For this study, we opted to use variance-based structural equation modeling estimated with partial least squares (PLS-SEM). These models are intended to predict and explain the variance of the endogenous construct under study (loyalty) by means of different latent variables that are predictors (cognitive image and satisfaction attributes).

Theoretical concepts of behavioural investigation are usually represented as latent variables according to Benitez et al. [148]. Following Dijkstra and Henseler [149], the use of PLSc is a recommended method to consistently estimates model in case the common 
factor model is true; and it is equally recommended in comparison with the covariance based structural equation modelling. Additionally, Dijkstra and Henseler conclude that the PLSc approach report less problems in the framework of non-recursive linear reflective model [149]. Among other reasons, these aforementioned facts justify the selection of PLSc. Later, we have computed the model with partial least squares structural equation modeling with the software SmartPLS version 3.3 [140] using PLSc to test the hypotheses.

Two phases englobe the assessment of the PLS-SEM: Firstly, the evaluation of the measurement model and, secondly, the assessment of the structural model. Concerning the mediation, Nitzl et al. [150] is followed. To end with this section and based on the literature review described earlier, we propose a confirmatory model with a nomogram (Figure 2) showing the relationships between the constructs, as well as the sign and direction of said relationships.

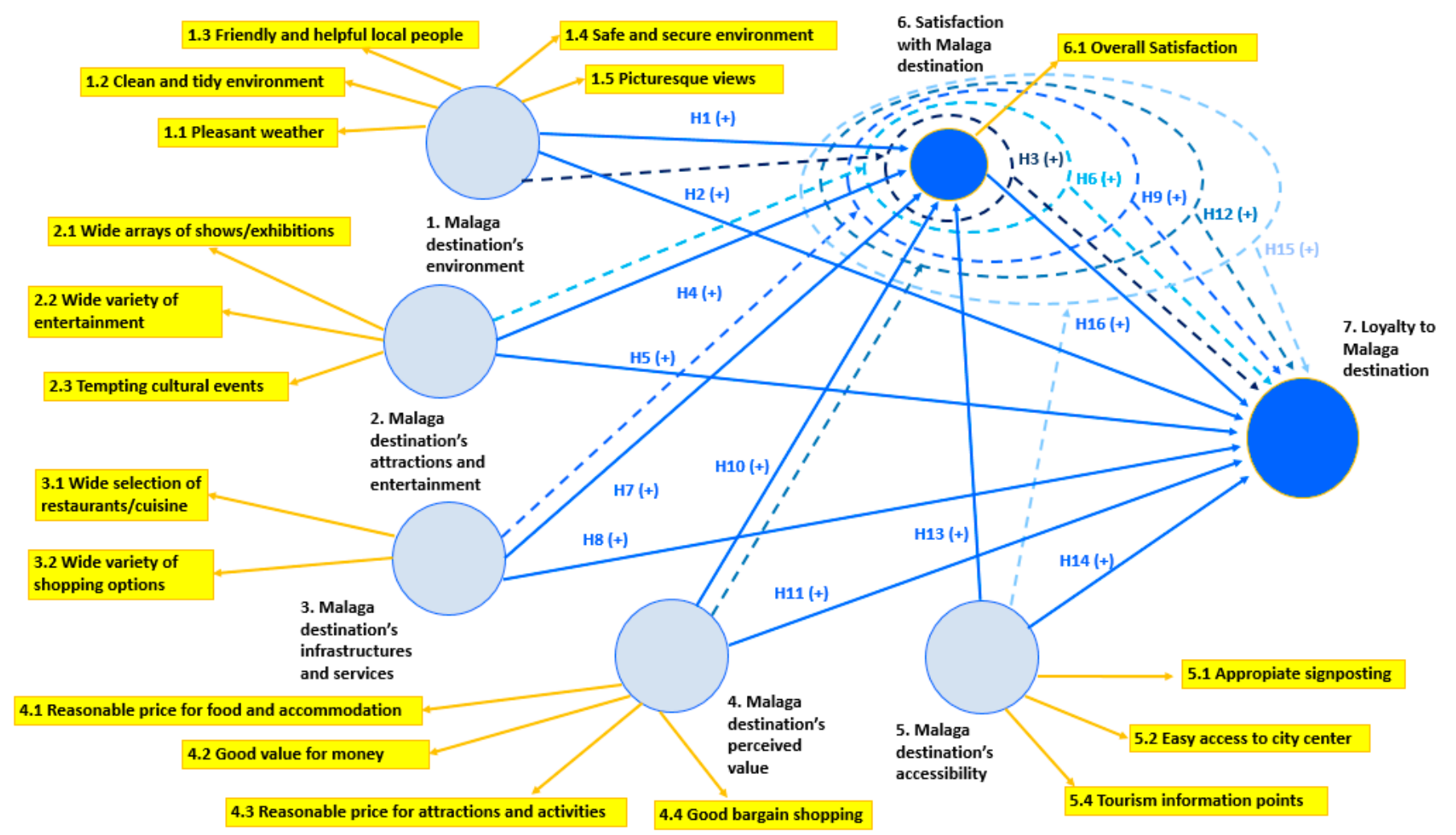

Figure 2. Confirmatory model. Source: Own elaboration using [140].

\section{Results}

\subsection{Measurement Model}

Following the recommendations based on the functionality of SmartPLS, PLSc was selected since the constructs are common factors. The evaluation of the measurement model of reflective constructs with its corresponding items included various assessments [151,152] item reliability, internal consistency reliability, convergent validity and discriminant validity.

Concerning the items removed from the measurement models, firstly, it should be noted the item 5.3 of construct accessibility was removed; the outer loading was below 0.6 and after removing from the model, AVE has increased $[153,154]$. Secondly, it was removed from infrastructure the indicator 3.3 variety of accommodation as we realize that cruise passengers do not spend nights in destination. The rest items from first construct environment with outer below 0.7 , but near of this value, were not removed due to content validity. 
Firstly, in regard to item reliability, the external load must be greater than or equal to 0.6 for an exploratory model and 0.7 for a confirmatory model (Tables 3 and A1 of Appendix A for more description). Secondly, internal consistency reliability was evaluated using composite reliability, [155,156], Dijkstra-Henseler RhoA and Cronbach's alpha [157], both of which must be greater than 0.7. Convergent validity was measured using the Average Variance Extracted (AVE) [158], which must be greater than 0.5. The aforementioned threshold requirements were all met in our case, as shown in Table 3.

Table 3. Item reliability, internal consistency reliability and convergent validity.

\begin{tabular}{|c|c|c|c|c|c|}
\hline Constructs Related to Malaga Destination & $\mathrm{CA}>0.7$ & RhoA $>0.7$ & $\mathrm{CR}>0.7$ & AVE $>0.7$ & $\begin{array}{c}\text { Factorial } \\
\text { Loadings } \\
\text { (Min.; Max.) }\end{array}$ \\
\hline 1. Environment & 0.836 & 0.843 & 0.838 & 0.510 & $(0.533 ; 0.823)$ * \\
\hline 2. Attractions and entertainment & 0.915 & 0.919 & 0.917 & 0.787 & $(0.736 ; 0.962)$ * \\
\hline 3. Infrastructure and service & 0.822 & 0.824 & 0.822 & 0.699 & $(0.735 ; 0.904)$ * \\
\hline 4. Perceived value & 0.859 & 0.861 & 0.860 & 0.606 & $(0.663 ; 0.851)$ * \\
\hline 5. Accessibility & 0.807 & 0.808 & 0.807 & 0.583 & $(0.681 ; 0.843)$ * \\
\hline 6. Satisfaction with destination ( 1 item) & 1 & 1 & 1 & 1 & $(1.000)$ \\
\hline 7. Loyalty with destination & 0.832 & 0.871 & 0.846 & 0.736 & $(0.680 ; 1.000)$ * \\
\hline
\end{tabular}

Note: CA: Cronbach's alpha; RhoA: Dijkstra-Henseler rho (also denotes by $\rho_{\mathrm{A}}$ ), CR: Composite reliability; AVE: Average variance extracted. Obtained from the $* 95 \%$ Confidence Intervals. Source: [140].

Multiple criteria can be used to analyze discriminant validity, which measures how different the constructs are from each other. In this case, two criteria were used: first, the criterion of Fornell and Larcker [158], which consists of comparing the correlations between constructs with the square root of the AVE and the correlations between constructs and any of said correlations exceeding the AVE; second, the Heterotrait-Monotrait ratio of correlations (HTMT), which should not exceed 0.90 [159]. All of the established threshold requirements for the measurement model evaluation were met in this study, according to the calculated values shown in Table 4.

Table 4. Discriminant validity: Fornell and Lacker versus Heterotrait-Monotrait Ratio criteria.

\begin{tabular}{|c|c|c|c|c|c|c|c|}
\hline Construct & 1. Environment & $\begin{array}{l}\text { 2. Attractions and } \\
\text { Entertainment }\end{array}$ & $\begin{array}{l}\text { 3. Infrastructures } \\
\text { and Services }\end{array}$ & $\begin{array}{l}\text { 4. Perceived } \\
\text { Value }\end{array}$ & 5. Accessibility & 6. Satisfaction & 7. Loyalty \\
\hline 1. Environment & 0.714 & 0.357 & 0.589 & 0.541 & 0.681 & 0.646 & 0.667 \\
\hline $\begin{array}{l}\text { 2. Attractions and } \\
\text { entertainment }\end{array}$ & 0.357 & 0.887 & 0.462 & 0.472 & 0.387 & 0.262 & 0.299 \\
\hline $\begin{array}{l}\text { 3. Infrastructures } \\
\text { and services }\end{array}$ & 0.592 & 0.460 & 0.836 & 0.555 & 0.590 & 0.408 & 0.425 \\
\hline 4. Perceived value & 0.539 & 0.470 & 0.556 & 0.778 & 0.608 & 0.472 & 0.467 \\
\hline 5. Accessibility & 0.679 & 0.386 & 0.589 & 0.607 & 0.763 & 0.538 & 0.508 \\
\hline 6. Satisfaction & 0.644 & 0.262 & 0.409 & 0.472 & 0.538 & 1.000 & 0.791 \\
\hline 7. Loyalty & 0.658 & 0.297 & 0.422 & 0.460 & 0.507 & 0.784 & 0.858 \\
\hline
\end{tabular}

Source: [140]. Note: The square of AVE in the diagonal. Constructs' inter-correlations under diagonal and HTMT values over the diagonal.

\subsection{Structural Model}

In this case, all of the bootstrap exact fit tests (the standardized root mean square Residual, SRMR, the unweighted least squares discrepancy, DULS, and the geodesic discrepancy, DG) of the assessed model were computed, providing no significant results $(p>0.005)$; thus, the model fit is not satisfactory. However, other scholars disagree with these requirements according to Chin et al. [160].

The structural model was evaluated according to the recommendations made in various studies $[147,161,162]$. The assessment of the internal model includes: (1) collinearity between constructs; (2) the model's predictive power using the coefficient of determination $\left(R^{2}\right)$ and the Stone Geisser $Q^{2}$ coefficient $[163,164]$, (3) evaluation of effect size $\mathrm{f}^{2}$; and (4) statistical significance and relevance of the path coefficients. 


\subsubsection{Collinearity Assessment}

In order to evaluate the degree of collinearity with the constructs preceding the endogenous construct, the software calculates the reciprocal of the tolerance (TOL); that is, the variance inflation factor (VIF $=1 / \mathrm{TOL}$ ). In the context of PLS-SEM, TOL values that are less than or equal to 0.20 , equivalent to VIF values greater than or equal to 5 , mean that there is a potential problem of collinearity [152]. Nevertheless, other authors use other thresholds, considering VIF values greater than 3.3 [165], as well as a value of 5 [166]. After calculating the VIF, the results indicate that there are no potential problems of collinearity between the latent variables (see Table 5).

Table 5. Variance inflation factor (VIF).

\begin{tabular}{lcc}
\hline \multicolumn{1}{c}{ Constructs' VIF } & 6. Satisfaction & 7. Loyalty \\
\hline 1. Environment & 2.109 & 2.560 \\
\hline 2. Attractions and entertainments & 1.388 & 1.389 \\
\hline 3. Infrastructure and services & 1.929 & 1.932 \\
\hline 4. Perceived value & 1.896 & 1.938 \\
\hline 5. Accessibility & 2.293 & 2.329 \\
\hline 6. Satisfaction & & 1.804 \\
\hline Source: [140].
\end{tabular}

\subsubsection{Predictive Power}

Two measurements were used to quantify the predictive power of this structural model: the coefficient of determination $R^{2}$ and Stone-Geisser $Q^{2}$ criteria. First, the coefficient of determination measures the model's predictive precision and $R^{2} \geq 0.1$ is recommended [167]. However, another criterion has been established, considering that values of $0.1,0.25$ and 0.5 are weak, moderate and substantial, respectively [147]. The results are greater than the minimum threshold $R^{2} \geq 0.1$, with loyalty values at $R^{2}=0.658$ and satisfaction at $R^{2}=0.446$ (next to substantial); therefore, our model has a substantial predictive power in relation to $\mathrm{R}^{2}$ (Table 6). The general rule indicates that a cross-validated redundancy of $\mathrm{Q}^{2}>0.5$ is considered to be a predictive model [139]. In this case, the $\mathrm{Q}^{2}$ criterion by Stone-Geisser is close to the established threshold in the case of loyalty (Table 6).

Table 6. Variance explained and cross-validated redundancy index.

\begin{tabular}{ccc}
\hline Dependent Construct & $\mathbf{R}^{2}$ & $\mathbf{Q}^{2}$ \\
\hline 6. Satisfaction & $0.446^{*}$ & 0.378 \\
7. Loyalty & $0.658^{*}$ & 0.466 \\
\hline
\end{tabular}

Source: [140]. Note. ${ }^{*} p<0.05$.

\subsubsection{Effect Size $\mathrm{f}^{2}$}

The change produced in the value of $\mathrm{R}^{2}$ by eliminating an exogenous latent variable from the structural model can be used to indicate whether the omitted construct has a substantial impact on the endogenous construct. This change is measured by the effect size $\left(\mathrm{f}^{2}\right)$. The construct's effect size measures the impact of the exogenous variable in the structural model's predictive power. Values in the range: $0.02 \leq \mathrm{f}^{2}<0.15,0.15<\mathrm{f}^{2} \leq 0.35$ and $\mathrm{f}^{2} \geq 0.35$ indicate weak, moderate and strong effects, respectively, according to Cohen [168]. In our case, all of the $f^{2}$ values fluctuate between 0.00 and 0.606 . The effect size of cruise tourists' satisfaction when explaining loyalty is strong $(0.606)$, the $\mathrm{f}^{2}$ of environment image when explaining satisfaction is moderate $(0.214)$. Moreover, the $\mathrm{f}^{2}$ of perceived value when explaining satisfaction (0.022) are weak likewise environment on loyalty (0.071). The rest of the effects are essentially non-existent or without any effect (0.000 to 0.016$)$, whether 
for the image of the rest of the latent variables when explaining satisfaction or the image of the rest of the constructs when explaining loyalty (Table A2).

\subsubsection{Path Coefficients, Significance and Relevance}

In bootstrapping, subsamples are created with randomly drawn observations (with replacement) from the original set of data, with the same sample size as the study's original sample (457 cases). To ensure the stability of the results, there must be a large number of subsamples. The significance of the normalized path coefficients was obtained through a bootstrap resampling procedure of 5000 samples of the same number of observations (457 cases), which is considered to be the ideal number of bootstrap samples $[169,170]$. The standardized path coefficients reported in the path diagram (Figure 3) are significant at a level of $5 \%$.

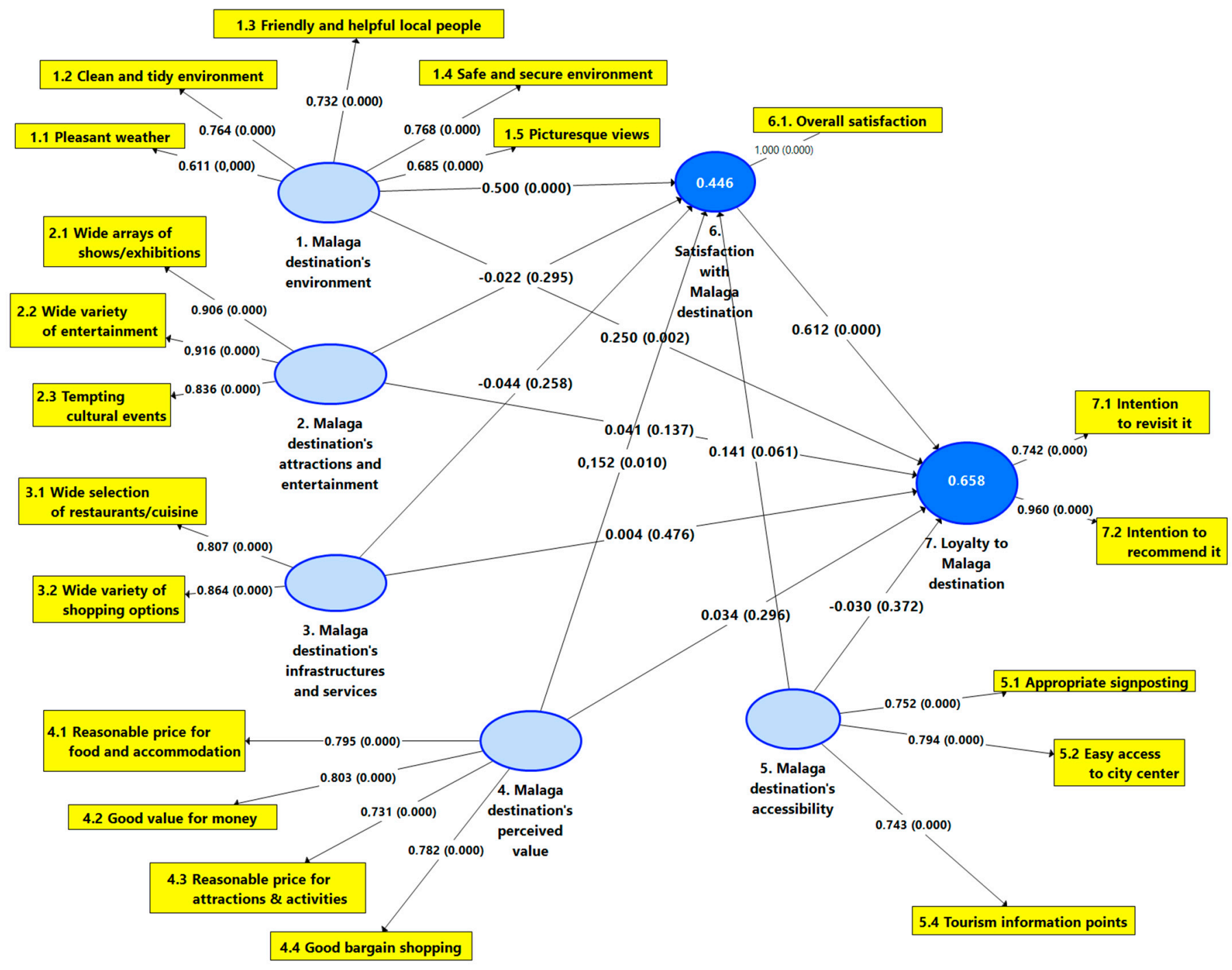

Figure 3. Tested model. Note: p-values in brackets. Source: Own elaboration from [140]. 
The relevance of the normalized path coefficients was obtained from the comparison between said coefficients, keeping in mind that the greater the value of these coefficients, greater the relevance. The direct path coefficients of the constructs of environment image and perceived value are significant and positive (Table 7) in relation to satisfaction, with environment image being the most relevant of the two image sub-dimensions with a value of 0.500 , followed by perceived value. However, the relationships between attractions and entertainment image, infrastructure and services and accessibility with satisfaction are not significant. In regard to loyalty, only the constructs of environment image and satisfaction have significant direct effects, with satisfaction having the most substantial effect (0.500) after satisfaction in loyalty (0.612). Furthermore, we included the variance account for (VAF) equals to the proportion that indirect effect represents from total effect (also in percentage). It is a supplementary and secondary criterion: VAF below $20 \%$ is considered no mediation; VAF between $20 \%$ and $80 \%$ is partial mediation and greater than $80 \%$ full mediation [147].

Table 7. Direct, indirect and total effect concerning to model for Malaga destination.

\begin{tabular}{|c|c|c|c|c|}
\hline HYPOS & Direct Path & $\begin{array}{c}\text { Coefficient } \\
\text { (Percent.Boot.95\%CI) }\end{array}$ & Sig. & \\
\hline supported & H1 Environment directly affects satisfaction. & $\begin{array}{c}0.500 \\
(0.392 ; 0.617)\end{array}$ & * & \\
\hline supported & H2 Environment directly affects loyalty. & $\begin{array}{c}0.250 \\
(0.103 ; 0.394)\end{array}$ & * & \\
\hline rejected & $\begin{array}{l}\text { H4 Attractions and entertainments image directly } \\
\text { affects satisfaction. }\end{array}$ & $\begin{array}{c}-0.022 \\
(-0.090 ; 0.042)\end{array}$ & NS & \\
\hline rejected & $\begin{array}{l}\text { H5 Attractions and entertainments image directly } \\
\text { affects loyalty. }\end{array}$ & $\begin{array}{c}0.041 \\
(-0.018 ; 0.103) \\
\end{array}$ & NS & \\
\hline rejected & $\begin{array}{l}\text { H7 Infrastructure and service image directly } \\
\text { affects satisfaction. }\end{array}$ & $\begin{array}{c}-0.044 \\
(-0.156 ; 0.064) \\
\end{array}$ & NS & \\
\hline rejected & $\begin{array}{l}\text { H8 Infrastructure and service image directly } \\
\text { affects loyalty. }\end{array}$ & $\begin{array}{c}0.004 \\
(-0.103 ; 0.106) \\
\end{array}$ & NS & \\
\hline supported & H10 Perceived value image directly affects satisfaction. & $\begin{array}{c}0.152 \\
(0.046 ; 0.254)\end{array}$ & * & \\
\hline rejected & H11 Perceived value image directly affects loyalty. & $\begin{array}{c}0.034 \\
(-0.072 ; 0.141) \\
\end{array}$ & NS & \\
\hline rejected & H13 Accessibility image directly affects satisfaction. & $\begin{array}{c}0.141 \\
(-0.014 ; 0.287) \\
\end{array}$ & NS & \\
\hline rejected & H14 Accessibility image directly affects loyalty. & $\begin{array}{c}-0.030 \\
(-0.186 ; 0.121)\end{array}$ & NS & \\
\hline \multirow[t]{2}{*}{ supported } & H16 Overall satisfaction affects loyalty. & $\begin{array}{c}0.612 \\
(0.508 ; 0.714)\end{array}$ & * & \\
\hline & Specific Indirect Path & $\begin{array}{c}\text { Coefficient } \\
\text { (Percent.Boot.95\%CI) }\end{array}$ & Sig. & VAF \\
\hline supported & $\begin{array}{l}\text { H3 Environment indirectly affects loyalty } \\
\text { through satisfaction. }\end{array}$ & $\begin{array}{c}0.306 \\
(0.230 ; 0.396) \\
\end{array}$ & * & $\begin{array}{l}55.07 \% \\
\text { partial mediation }\end{array}$ \\
\hline rejected & $\begin{array}{l}\text { H6 Attractions and entertainments affects loyalty } \\
\text { indirectly through satisfaction. }\end{array}$ & $\begin{array}{c}-0.013 \\
(-0.057 ; 0.025)\end{array}$ & NS & - \\
\hline rejected & $\begin{array}{l}\text { H9 Infrastructure and service image affects loyalty } \\
\text { indirectly through satisfaction. }\end{array}$ & $\begin{array}{c}-0.027 \\
(-0.096 ; 0.040)\end{array}$ & NS & - \\
\hline supported & $\begin{array}{c}\text { H12 Perceived value image affects loyalty indirectly } \\
\text { through satisfaction. }\end{array}$ & $\begin{array}{c}0.093 \\
(0.028 ; 0.159)\end{array}$ & * & $\begin{array}{l}73.30 \% \\
\text { partial mediation }\end{array}$ \\
\hline rejected & $\begin{array}{c}\text { H15 Accessibility image affects loyalty indirectly } \\
\text { through satisfaction. }\end{array}$ & $\begin{array}{c}0.086 \\
(-0.008 ; 0.182)\end{array}$ & NS & - \\
\hline
\end{tabular}


Table 7. Cont.

\begin{tabular}{|c|c|c|c|}
\hline & Total $=$ Direct + Indirect & $\begin{array}{c}\text { Coefficient } \\
\text { (Percent.Boot.95\%CI) }\end{array}$ & Sig. \\
\hline Direct effect & H1 Environment influences on satisfaction. & $\begin{array}{c}0.500 \\
(0.392 ; 0.617)\end{array}$ & * \\
\hline $\begin{array}{l}\text { Direct and } \\
\text { indirect }\end{array}$ & H2 Environment influences on loyalty. & $\begin{array}{c}0.556 \\
(0.410 ; 0.707)\end{array}$ & * \\
\hline No effect & $\begin{array}{l}\text { H4 Attractions and entertainments influences } \\
\text { on satisfaction. }\end{array}$ & $\begin{array}{c}-0.022 \\
(-0.090 ; 0.042) \\
\end{array}$ & NS \\
\hline No effect & H5 Attractions and entertainments influences on loyalty. & $\begin{array}{c}0.028 \\
(-0.042 ; 0.101) \\
\end{array}$ & NS \\
\hline No effect & H7 Infrastructure and service influences on satisfaction. & $\begin{array}{c}-0.044 \\
(-0.156 ; 0.064)\end{array}$ & NS \\
\hline No effect & H8 Infrastructure and service influences on loyalty. & $\begin{array}{c}-0.023 \\
(-0.153 ; 0.102) \\
\end{array}$ & NS \\
\hline Direct effect & H10 Perceived value influences on satisfaction. & $\begin{array}{c}0.152 \\
(0.046 ; 0.254)\end{array}$ & * \\
\hline $\begin{array}{c}\text { Direct and } \\
\text { indirect }\end{array}$ & H11 Perceived value influences on loyalty. & $\begin{array}{c}0.127 \\
(0.011 ; 0.240)\end{array}$ & * \\
\hline No effect & H3 Accessibility influences on satisfaction. & $\begin{array}{c}0.141 \\
(-0.014 ; 0.287) \\
\end{array}$ & NS \\
\hline No effect & H14 Accessibility influences on loyalty. & $\begin{array}{c}0.056 \\
(-0.121 ; 0.228) \\
\end{array}$ & NS \\
\hline Direct effect & H16 Satisfaction influences on loyalty. & $\begin{array}{c}0.612 \\
(0.508 ; 0.714)\end{array}$ & $*$ \\
\hline
\end{tabular}

Note: HYPOS, hypotheses, Perc.Boot.CI, Percentile bootstrap confidence intervals, Sig.: Significant, NS: Not significant. *: $p<0.05$. Variance account for (VAF). Source: Own from [140].

Considering that the direct effects of the other constructs of the destination's cognitive image are not significant in relation to loyalty, it is interesting to study the mediating role of satisfaction on said constructs and classify all these relationships. In the case of attractions and entertainment, infrastructure and services and, finally, in accessibility, there is no mediation; that is, they have no effect on loyalty, as both the direct and indirect effects are not statistically significant. Additionally, satisfaction is a partial collaborativecomplementary-mediator between environment image and loyalty likewise perceived value and loyalty is (Table 8 ). Whether the direct or indirect path coefficients are significant or not is repeated in Table 8, summarizing the comparisons under consideration. Furthermore, Figure 3 offers a comprehensive visualization of the path model for the estimated model. 
Table 8. Mediation analysis of satisfaction.

\begin{tabular}{|c|c|c|c|c|}
\hline Path & Sig. & Sign & Hypotheses & $\begin{array}{l}\text { Result of Satisfaction as Mediator between Each } \\
\text { Image's Sub-Dimension and Loyalty }\end{array}$ \\
\hline Environment directly affects loyalty. & Yes & $(+)$ & \multirow{2}{*}{$\begin{array}{l}\text { H3: Satisfaction mediates between } \\
\text { environment and loyalty. }\end{array}$} & H3 supported. \\
\hline Environment affects indirectly to loyalty through satisfaction. & Yes & $(+)$ & & $\begin{array}{l}\text { Type of mediation: partial and positive. } \\
\text { It is a collaborative-complementary-partial mediator. }\end{array}$ \\
\hline \multicolumn{5}{|c|}{ Conclusion: Satisfaction mediates between environment and loyalty through satisfaction, partially and positively. } \\
\hline Attraction and entertainment directly affects loyalty. & No & & $\begin{array}{l}\text { H6: Satisfaction mediates between attraction } \\
\text { and entertainment and loyalty. }\end{array}$ & H6 rejected. \\
\hline \multicolumn{5}{|c|}{$\begin{array}{l}\text { Conclusion: Satisfaction does not mediate between attractions and entertainments and loyalty. } \\
\text { Attraction and entertainment have no effect on loyalty (neither direct nor indirect) }\end{array}$} \\
\hline Infrastructure and services directly affects loyalty. & No & & \multirow{2}{*}{$\begin{array}{l}\text { H9: Satisfaction mediates between } \\
\text { infrastructure and services and loyalty. }\end{array}$} & H9 rejected. \\
\hline Infrastructure and services indirectly affects loyalty. & No & & & No effect, no mediation. \\
\hline
\end{tabular}

Conclusion respect to infrastructure and services: Satisfaction mediates between infrastructure and services and loyalty through satisfaction. Infrastructure and services have no effect on loyalty (neither direct nor indirect)

\begin{tabular}{|c|c|c|c|c|}
\hline Perceived value directly affects loyalty. & Yes & $(+)$ & \multirow{2}{*}{$\begin{array}{l}\text { H12: Satisfaction mediates between perceived } \\
\text { value and loyalty. }\end{array}$} & H12 supported. \\
\hline Perceived value indirectly affects loyalty. & Yes & $(+)$ & & $\begin{array}{l}\text { Type of mediation: partial and positive. } \\
\text { It is a collaborative-complementary-partial mediator. }\end{array}$ \\
\hline \multicolumn{5}{|c|}{ Conclusion: Satisfaction mediates between perceived value and loyalty through satisfaction, partially and positively. } \\
\hline Accessibility directly affects loyalty. & No & & $\begin{array}{l}\text { H15: Satisfaction mediates between } \\
\text { accessibility and loyalty. }\end{array}$ & H15 rejected. \\
\hline Accessibility indirectly affects loyalty. & No & & & No effect, no mediation. \\
\hline
\end{tabular}

Note: Sig.: Significant at level 5\% based on one-side test. Source: Own elaboration. 


\section{Discussions and Conclusions}

\subsection{Theoretical Implications}

This study presents a model that explains the influence of the cognitive attributes of tourist destination image on destination loyalty, as well as the mediating role of cruisers' overall satisfaction between each of these attributes and loyalty. One of the most relevant elements of this research as compared to other prior studies is the consideration of the individual influence of each of the attributes of cognitive destination image on both cruisers' satisfaction and loyalty. The few prior studies on cruise tourism offer overall results of destination image as a second-order construct, providing generic conclusions about its influence on satisfaction and loyalty $[22,27,88,89]$. However, this study allows us to answer which specific constructs of cognitive image are determining factors of cruisers' satisfaction and which constructs influence destination loyalty.

In comparison with Chi and Qu's research [12], our study includes the image destination in sub-dimensions in the model; meanwhile, Chi and Qu considered a construct of the overall image destination. Similarly, we also analyze direct and indirect effects of image through overall satisfaction. Specifically, our model is a sub-model of these authors with the novelty of considering the image divided into different dimensions in order to detect which constructs affects more to the satisfaction and the loyalty. Finally, this survey was conducted during the whole year; therefore, seasonality may not restrict the research findings to summer tourists.

With regards to Chen and Phou [66], they did not assess the destination image direct relation to loyalty with destination, only indirectly through the satisfaction. Similarly, we do assess the cognitive dimension of the destination image; however, they did this as an overall image, while in our study, the destination image is divided into five dimensions, as we have mentioned above.

From the results of this study, we can conclude that a destination's environment image is the attribute of cognitive image that has the greatest influence on cruisers' overall satisfaction, through a direct, positive, substantial relationship. This conclusion is in line with the study by Sanz-Blas and Carvajal-Trujillo [96], which demonstrates that the travel environment is the component of destination image that plays the most decisive role in cruisers' satisfaction in Valencia (Spain). However, in a study about the destination Ensenada (Baja California), Toudert and Bringas-Rabago [27] consider that although environment image has a significant direct effect on satisfaction, it has less of an influence than other cognitive components such as a destination's attractions and entertainment and the urban environment. These coincidences may be due to the fact that both destinations Valencia and Malaga are Mediterranean ports and, therefore, present a similar conception of environment image as compared to destinations at other latitudes, such as Ensenada. It also may be possible that cruisers in the Mediterranean have different expectations and that factors such as climate and picturesque views are more decisive in the construct of satisfaction than in other types of cruises, depending on their destinations. Ultimately, maintaining a pleasant, distinguishable environment should satisfactorily meet cruisers' motivations and expectations, as suggested by Qu and Ping [171].

Attributes such as the destination's attractions and entertainment image, or the image of infrastructure such as restaurants, hotels and shops, do not have an influence on cruisers' satisfaction or destination loyalty. These results corroborate the results obtained by SanzBlas et al. [89] and, partially, by Toudert and Bringas-Rábago [27], since the latter authors conclude that attractions are especially relevant.

On the other hand, cognitive attributes of the destination's image such as accessibility and the perceived value of services do have a direct influence on cruisers' satisfaction and also have an indirect influence on loyalty, to a lesser degree, although it has a weaker effect than environment image. These conclusions are in line with the results of a study conducted by Meng et al. [88], which were obtained from the opinions of passengers on the Star Cruise line. 
Another important finding of this article is that environment image not only has an influence on cruisers' satisfaction, but that it also has a positive, direct, significant relationship with destination loyalty. These results are in accordance with the findings of DiPietro and Peterson [25], who also concluded that positive experiences with environment image contribute to cruisers revisiting and recommending a destination. However, these results differ from those obtained by Silvestre et al. [26] in regard to a similar construct that does not influence cruisers' loyalty.

Perceived value does not have a direct influence on loyalty; however, it does have an indirect effect through satisfaction, which acts as a total mediator in this case, although the indirect effect is weak. While these results are in line with the findings of various authors [124,125], they differ from those obtained by Murphy et al. [114] in regard to the direct relationship between the perceived value of tourism services and loyalty. Similarly, accessibility only has an indirect influence on loyalty through the mediation of satisfaction. This may be due to the fact that cruisers' assessment of accessibility depends on a positive perception of overall satisfaction.

Along these lines, the conclusion that cruisers' overall satisfaction has a decisive influence on loyalty confirms what has been established by prior studies, both in the tourism sector in general [13-15] and in cruise tourism in particular [96,134].

Finally, the results of this study corroborate the mediating role of satisfaction between image and loyalty, in accordance with the results obtained by other authors in both a general context $[12,84,86,130]$ and within the specific context of cruises $[16,27]$.

\subsection{Managerial Implications}

The attributes of cognitive image that have a significant influence on cruisers' satisfaction and loyalty (environment image, perceived value and accessibility) fall under the responsibility of destination management organizations such as city councils, business owners, trade associations and other public and private institutions. These institutions must proactively manage the variables that can produce satisfactory experiences for cruisers and help them develop a bond, both cognitive and emotional, when visiting the city.

The confirmation that overall satisfaction influences loyalty enables management organizations to develop more efficient loyalty strategies for their respective destinations. Therefore, if the goal is to get cruisers to return to the destination or for them to recommend it to the people they know, it is of the utmost importance to focus on issues of cleanliness, picturesque locations, safety and hospitality. These variables (which pertain to the attribute environment image) have the greatest influence on cruisers' satisfaction and loyalty, both directly and indirectly.

Meeting the expectations that cruisers associate with a destination's image is also crucial in this process of producing satisfaction and, consequently, loyalty. Otherwise, not only does it limit the likelihood of cruisers revisiting a destination, it also means that they would not give positive feedback about the destination to the people they know. If cruisers were to revisit the destination on another cruise, it would actively contribute to moderating the significant seasonality of hotels in the city of Malaga.

We believe that it is crucial to involve not only relevant institutions, but also the destination's local residents through appropriate communication and loyalty strategies for these kinds of initiatives, for example, through challenges, public greetings or promotional messages regarding the importance of welcoming cruise tourists and their significance in the local economy. These initiatives should be integrated in the destination's marketing and strategic plans.

\subsection{Limitations and Suggestions for Future Research}

This study reveals various limitations in addition to laying the groundwork for future research. One limitation to keep in mind is that the data refers to a specific port in the Mediterranean, which has specific, unique characteristics that are different from other ports 
of a similar scale. Similarly, the data were collected just before the emergence of COVID-19 and its consequences for cruise ships and their respective destinations.

It would, therefore, be important for future studies to expand the field of research, conducting a comparison with other destination ports that have other characteristics that differ from the Mediterranean. It would also be interesting to apply panel data using information post-COVID-19, in addition to the prior data that were collected. Lastly, we recommend expanding the cognitive attributes of the destination's image, considering the specific health risks associated with the disease and the destination's healthcare system.

Supplementary Materials: The following are available online at https:/ /www.mdpi.com/article/10 .3390/math9111218/s1, Table S1: Survey items about the city of Malaga (Andalusia, Spain).

Author Contributions: Conceptualization, E.M.S.-T.; G.B.-G.; methodology, software, validation, formal analysis, M.D.B.-M.; investigation, M.D.B.-M.; E.M.S.-T.; G.B.-G.; E.C.-R.; resources, G.B.-G.; E.C.-R.; data curation, G.B.-G.; E.C.-R.; writing—original draft preparation M.D.B.-M.; E.M.S.-T.; G.B.G.; writing-review and editing, M.D.B.-M.; E.M.S.-T.; G.B.-G.; supervision, M.D.B.-M.; E.M.S.-T.; G.B.-G. All authors have read and agreed to the published version of the manuscript.

Funding: This research received no external funding.

Institutional Review Board Statement: Not applicable. All subjects gave their informed consent for inclusion before they participated in the study. The study was conducted in accordance with the Declaration of Helsinki.

Informed Consent Statement: Informed consent was obtained from all subjects involved in the study.

Data Availability Statement: Data available on request due to restrictions privacy. The data are not publicly available due to further researching.

Acknowledgments: We would like to thank two anonymous reviewers for helpful comments on this paper.

Conflicts of Interest: The authors declare no conflict of interest.

Appendix A

Table A1. Outer loadings.

\begin{tabular}{|c|c|c|c|c|c|}
\hline $\begin{array}{l}\text { Constructs } \\
\text { Indicators }\end{array}$ & Outer Loadings & t Statistics & $p$-Value & $5.0 \%$ & $95.0 \%$ \\
\hline \multicolumn{6}{|l|}{ 1. Environment } \\
\hline 1.1. Pleasant weather & 0.611 & 13.572 & 0.000 & 0.533 & 0.681 \\
\hline 1.2. Clean and tidy environment & 0.764 & 21.962 & 0.000 & 0.704 & 0.818 \\
\hline 1.3. Friendly and helpful local people & 0.732 & 19.363 & 0.000 & 0.669 & 0.793 \\
\hline 1.4. Safe and secure environment & 0.768 & 22.219 & 0.000 & 0.709 & 0.823 \\
\hline 1.5. Picturesque views & 0.685 & 14.857 & 0.000 & 0.604 & 0.757 \\
\hline \multicolumn{6}{|l|}{ 2. Attractions and entertainment } \\
\hline 2.1. Wide arrays of shows/exhibitions & 0.906 & 26.209 & 0.000 & 0.847 & 0.962 \\
\hline 2.2. Wide variety of entertainment & 0.916 & 31.524 & 0.000 & 0.866 & 0.962 \\
\hline 2.3. Tempting cultural events & 0.836 & 14.684 & 0.000 & 0.736 & 0.919 \\
\hline \multicolumn{6}{|l|}{ 3. Infrastructure and service } \\
\hline 3.1. Wide selection of restaurants/cuisine & 0.807 & 25.841 & 0.000 & 0.754 & 0.857 \\
\hline 3.2. Wide variety of shopping options & 0.864 & 33.260 & 0.000 & 0.819 & 0.904 \\
\hline 3.3. Wide choice of accommodations & - & - & - & - & - \\
\hline \multicolumn{6}{|l|}{ 4. Perceived value } \\
\hline 4.1. Reasonable price for food and accommodation & 0.795 & 23.608 & 0.000 & 0.735 & 0.847 \\
\hline 4.2. Good value for money & 0.803 & 25.353 & 0.000 & 0.749 & 0.851 \\
\hline 4.3. Reasonable price for attractions and activities & 0.731 & 18.390 & 0.000 & 0.663 & 0.793 \\
\hline 4.4. Good bargain shopping & 0.782 & 18.252 & 0.000 & 0.710 & 0.850 \\
\hline
\end{tabular}


Table A1. Cont.

\begin{tabular}{|c|c|c|c|c|c|}
\hline $\begin{array}{l}\text { Constructs } \\
\text { Indicators }\end{array}$ & Outer Loadings & t Statistics & $p$-Value & $5.0 \%$ & $95.0 \%$ \\
\hline \multicolumn{6}{|l|}{ 5. Accessibility } \\
\hline 5.1. Appropriate signposting & 0.752 & 23.573 & 0.000 & 0.699 & 0.804 \\
\hline 5.2. Easy access to city center & 0.794 & 25.280 & 0.000 & 0.741 & 0.843 \\
\hline 5.3. Disabled access & - & - & - & - & - \\
\hline 5.4. Tourism information points & 0.743 & 20.796 & 0.000 & 0.681 & 0.799 \\
\hline \multicolumn{6}{|l|}{ 6. Satisfaction with destination ( 1 item) } \\
\hline 6.1. Overall satisfaction & 1.000 & & & 1.000 & 1.000 \\
\hline \multicolumn{6}{|l|}{ 7. Loyalty with destination } \\
\hline 7.1. Intention to revisit it & 0.742 & 21.059 & 0.000 & 0.680 & 0.798 \\
\hline 7.2. Intention to recommend & 0.960 & 38.125 & 0.000 & 0.918 & 1.002 \\
\hline
\end{tabular}

Source: Own elaboration from [140].

Table A2. Effect size $\mathrm{f}^{2}$.

\begin{tabular}{|c|c|c|c|}
\hline Constructs Related to Malaga Destination & $\mathbf{f}^{2}$ & $p$-Value & Type \\
\hline Environment on satisfaction & 0.214 & 0.002 & Moderate \\
\hline Environment on loyalty & 0.071 & 0.112 & Weak \\
\hline Attractions and entertainments on satisfaction & 0.001 & 0.439 & \\
\hline Attractions and entertainments on loyalty & 0.004 & 0.333 & \\
\hline Infrastructure and servicies on satisfaction & 0.002 & 0.413 & \\
\hline Infrastructure and servicies on loyalty & 0.000 & 0.499 & \\
\hline Perceived value on satisfaction & 0.022 & 0.126 & Moderate \\
\hline Perceived value on loyalty to destination & 0.002 & 0.443 & \\
\hline Accessibility on satisfaction with destination & 0.016 & 0.243 & \\
\hline Accessibility on loyalty to destination & 0.001 & 0.476 & \\
\hline Satisfaction with destination on loyalty & 0.606 & 0.002 & Substantial \\
\hline
\end{tabular}

Source: Own elaboration from [140].

\section{References}

1. Pickle, H.; Abrahamson, R.; Porter, A. Customer satisfaction and profit in small business. J. Retail. 1970, 46, 38.

2. Gnagi, P.; Bischofberger, J. Customer Satisfaction as the Way to Business Success; Tekstil: Zagreb, Croatia, 1995.

3. Jones, T.O.; Sasser, W.E. Why satisfied customers defect. Harv. Bus. Rev. 1995, 76, 88-99. [CrossRef]

4. Oliver, R.L. Whence consumer loyalty. J. Mark. 1999, 63, 33-44. [CrossRef]

5. Reichheld, F.F. Learning from customer defections. Harv. Bus. Rev. 1996, 74, 56-69.

6. $\mathrm{Su}, \mathrm{H} . ;$ Cheng, K.F.; Huang, H.H. Empirical study of destination loyalty and its antecedent: The perspective of place attachment. Serv. Ind. J. 2011, 31, 2721-2739. [CrossRef]

7. Chiu, W.; Zeng, S.; Cheng, P.S.T. The influence of destination image and tourist satisfaction on tourist loyalty: A case study of Chinese tourists in Korea. Int. J. Cult. Tour. Hosp. Res. 2016, 10, 223-234. [CrossRef]

8. Zhang, X.; Fu, L.; Cai, L.A.; Lu, L. Destination image and tourist loyalty: A meta-analysis. Tour. Manag. 2014, 40, 213-223. [CrossRef]

9. Baldinger, A.A.; Rubionson, J. Brand loyalty: Link between attitudes and behaviors. J. Mark. Resk. 1996, 36, 22-34.

10. Chen, C.F.; Tsai, D. How destination image and evaluative factors affect behavioral intentions. Tour Manag. 2007, 28, 1115-1122. [CrossRef]

11. Krishna, A.; Schwarz, N. Sensory perception, embodiment, and grounded cognition: Implications for consumer behavior. J. Consum. Psychol. 2014, 24, 453-459. [CrossRef]

12. Chi, C.G.Q.; Qu, H. Examining the structural relationships of destination image, tourist satisfaction and destination loyalty: An integrated approach. Tour. Manag. 2008, 29, 624-636. [CrossRef]

13. Cronin, J.; Brady, M.; Hult, G. Assessing the effects of quality, value, and customer satisfaction on consumer behavioral intentions in service environments. J. Retail. 2000, 76, 193-218. [CrossRef]

14. Oppermann, M. Tourism destination loyalty. J. Travel Res. 2000, 39, 78-84. [CrossRef]

15. Petrick, J.F.; Morais, D.D.; Norman, W.C. An examination of the determinants of entertainment vacationers' intentions to revisit. J. Travel Res. 2001, 40, 41-48. [CrossRef]

16. Albaity, M.; Melhem, S.B. Novelty seeking, image, and loyalty. The mediating role of satisfaction and moderating role of length of stay: International tourists' perspective. Tour. Manag. Perspect. 2017, 23, 30-37. [CrossRef] 
17. Lee, S.W.; Xue, K. A model of destination loyalty: Integrating destination image and sustainable tourism. Asia Pac. J. Tour. Res. 2020, 25, 393-408. [CrossRef]

18. Lordanova, E. Tourism destination image as an antecedent of destination loyalty: The case of Linz, Austria. Eur. J. Tour. Res. 2017, $16,214-232$.

19. Del Bosque, I.R.; San Martín, H. Tourist satisfaction a cognitive-affective model. Ann. Tour. Res. 2008, 35, 551-573. [CrossRef]

20. Lv, X.; McCabe, S. Expanding theory of tourists' destination loyalty: The role of sensory impressions. Tour. Manag. 2020, 77, 104026. [CrossRef]

21. Chua, B.L.; Lee, S.; Han, H. Consequences of cruise line involvement: A comparison of first-time and repeat passengers. Int. J. Contemp. Hosp. Manag. 2017, 29, 1658-1683. [CrossRef]

22. Han, H.; Hyun, S.S. Role of motivations for luxury cruise traveling, satisfaction, and involvement in building traveler loyalty. Int. J. Hosp. Manag. 2018, 70, 75-84. [CrossRef]

23. Han, H.; Eom, T.; Chung, H.; Lee, S.; Ryu, H.B.; Kim, W. Passenger repurchase behaviours in the green cruise line context: Exploring the role of quality, image, and physical environment. Sustainability 2019, 11, 1985. [CrossRef]

24. Hwang, J.; Hyun, S.S. Perceived firm innovativeness in cruise travelers' experience and perceived luxury value: The moderating effect of advertising effectiveness. Asia Pac. J. Tour. Res. 2016, 21 (Suppl. S1), S101-S128. [CrossRef]

25. DiPietro, R.B.; Peterson, R. Exploring cruise experiences, satisfaction, and loyalty: The case of Aruba as a small-island tourism economy. Int. J. Hosp. Tour. Adm. 2017, 18, 41-60. [CrossRef]

26. Silvestre, A.L.; Santos, C.M.; Ramalho, C. Satisfaction and behavioural intentions of cruise passengers visiting the Azores. Tour. Econ. 2008, 1, 169-184. [CrossRef]

27. Toudert, D.; Bringas-Rábago, N.L. Impact of the destination image on cruise repeater's experience and intention at the visited port of call. Ocean Coast. Manag. 2016, 130, 239-249. [CrossRef]

28. Puertos del Estado. Ministerio de Transporte, Movilidad y Agenda Urbana, 2020. Available online: http://www.puertos.es/eses/estadisticas/Paginas/estadistica_mensual.aspx (accessed on 11 August 2020).

29. Puertos del Estado. Ministerio de Transporte, Movilidad y Agenda Urbana. Los Puertos Españoles Superan los 9 Millones de Cruceristas en 2017. 2018. Available online: http:/ / www.puertos.es/es-es/Paginas/Noticias/Fitur2018.aspx (accessed on 11 August 2020).

30. United Nations World Tourism Organization. Available online: https:/ /www.e-unwto.org/loi/wtobarometereng?expanded=d2 010 (accessed on 14 July 2020).

31. Boulding, K.E. General systems-theory-The skeleton of science. Manag. Sci. 1956, 2, 197-208. [CrossRef]

32. Martineau, P. Sharper focues for the corporate image. Harv. Bus. Rev. 1958, 36, 49-58.

33. Chon, K.S. Traveler destination image modification process and its marketing implications. In Proceedings of the 1990 Academy of Marketing Science (AMS) Annual Conference; Springer: Cham, Switzerland, 2015; pp. 480-482.

34. Crompton, J.L.; Ankomah, P.K. Choice set propositions in destination decisions. Ann. Tour. Res. 1993, 20, 461-476. [CrossRef]

35. Echtner, C.M.; Ritchie, J.B. The measurement of destination image: An empirical assessment. J. Travel Res. 1993, 31, 3-13. [CrossRef]

36. Chen, J.S.; Hsu, C.H.C. Measurement of Korean tourists' perceived images of overseas destinations. J. Travel Res. 2000, 38. [CrossRef]

37. Driscoll, A.; Lawson, R.; Niven, B. Measuring tourists' destination perceptions. Ann. Tour. Res. 1994, 21, 499-511. [CrossRef]

38. Govers, R.; Go, F.M.; Kumar, K. Virtual destination image a new measurement approach. Ann. Tour. Res. 2007, 34, 977-997. [CrossRef]

39. Phelps, A. Holiday destination image-The problem of assessment: An example developed in Menorca. Tour. Manag. 1986, 7, 168-180. [CrossRef]

40. Prayag, G.; Hosany, S.; Muskat, B.; Del Chiappa, G. Understanding the relationships between tourists' emotional experiences, perceived overall image, satisfaction, and intention to recommend. J. Travel Res. 2017, 56, 41-54. [CrossRef]

41. Beerli, A.; Martin, J.D. Factors influencing destination image. Ann. Tour. Res. 2004, 31, 657-681. [CrossRef]

42. Jeong, Y.; Kim, S. A study of event quality, destination image, perceived value, tourist satisfaction, and destination loyalty among sport tourists. Asia Pac. J. Mark. Logist. 2019, 940-960. [CrossRef]

43. Baloglu, S.; McCleary, K.W. US international pleasure travelers' images of four Mediterranean destinations: A comparison of visitors and nonvisitors. J. Travel Res. 1999, 38, 144-152. [CrossRef]

44. Dann, G.M. Tourists' images of a destination-an alternative analysis. J. Travel Res. 1996, 5, 41-55. [CrossRef]

45. Gallarza, M.G.; Saura, I.G.; García, H.C. Destination image: Towards a conceptual framework. Ann. Tour. Res. 2002, 29 , 56-78. [CrossRef]

46. Ruan, W.Q.; Li, Y.Q.; Liu, C.H.S. Measuring tourism risk impacts on destination image. Sustainability 2017, 9, 1501. [CrossRef]

47. Hallmann, K.; Zehrer, A.; Müller, S. Perceived destination image: An image model for a winter sports destination and its effect on intention to revisit. J. Travel Res. 2015, 54, 94-106. [CrossRef]

48. Yacout, O.M.; Hefny, L.I. Use of Hofstede's cultural dimensions, demographics, and information sources as antecedents to cognitive and affective destination image for Egypt. J. Vacat. Mark. 2015, 21, 37-52. [CrossRef]

49. Agapito, D.; Oom do Valle, P.; da Costa Mendes, J. The cognitive-affective-conative model of destination image: A confirmatory analysis. J. Travel Tour. Mark. 2013, 30, 471-481. [CrossRef] 
50. Woosnam, K.M.; Stylidis, D.; Ivkov, M. Explaining conative destination image through cognitive and affective destination image and emotional solidarity with residents. J. Sustain. Tour. 2020, 28, 917-935. [CrossRef]

51. Chen, J.S.; Uysal, M. Market positioning analysis: A hybrid approach. Ann. Tour. Res. 2002, 29, 987-1003. [CrossRef]

52. Gartner, W.C. Image formation process. J. Travel Tour. Mark. 1994, 2, 191-216. [CrossRef]

53. Kim, H.; Richardson, S.L. Motion picture impacts on destination images. Ann. Tour. Res. 2003, 30, 216-237. [CrossRef]

54. Walmsley, D.J.; Jenkins, J.M. Appraisive images of tourist areas: Application of personal constructs. Aust. Geogr. 1993, 24, 1-13. [CrossRef]

55. Bigné Alcañiz, E.; Sánchez García, I.; Sanz Blas, S. The functional-psychological continuum in the cognitive image of a destination: A confirmatory analysis. Tour. Manag. 2009, 30, 715-723. [CrossRef]

56. Pike, S.; Ryan, C. Destination positioning analysis through a comparison of cognitive, affective, and conative perceptions. J. Travel Res. 2004, 42, 333-342. [CrossRef]

57. Xie, K.L.; Lee, J.S. Toward the perspective of cognitive destination image and destination personality: The case of Beijing. J. Travel Tour. Mark. 2013, 30, 538-556. [CrossRef]

58. Bigné, J.E.; Sánchez, M.I.; Sánchez, J. Tourism image, evaluation variables and after purchase behaviour: Inter-relationship. Tour. Manag. 2001, 22, 607-616. [CrossRef]

59. Konecnik, M.; Gartner, W.C. Customer-based brand equity for a destination. Ann. Tour. Res. 2007, 34, 400-421. [CrossRef]

60. Baker, D.A.; Crompton, J.L. Quality, satisfaction and behavioral intentions. Ann. Tour. Res. 2000, 27, 785-804. [CrossRef]

61. Li, R.X.; Petrick, J.F. Revisiting the commitment-loyalty distinction in a cruising context. J. Leis. Res. 2010, 42, 67-90. [CrossRef]

62. Kim, D.; Perdue, R.R. The effects of cognitive, affective, and sensory attributes on hotel choice. Int. J. Hosp. Manag. 2013, 35, 246-257. [CrossRef]

63. Kim, S.; Yoon, Y. The hierarchical effects of affective and cognitive components on tourism destination image. J. Travel Tour. Mark. 2003, 14, 1-22. [CrossRef]

64. Li, M.; Cai, L.A.; Lehto, X.Y.; Huang, J.Z. A missing link in understanding revisit intention-The role of motivation and image. J. Travel Tour. Mark. 2010, 27, 335-348. [CrossRef]

65. Walmsley, D.; Young, M. Evaluative images and tourism: The use of personal constructs to describe the structure of destination images. J. Travel Res. 1998, 36, 65-69. [CrossRef]

66. Chen, C.F.; Phou, S. A closer look at destination: Image, personality, relationship and loyalty. Tour. Manag. 2013, 36, 269-278. [CrossRef]

67. Chon, K.S. Tourism destination image modification process: Marketing implications. Tour. Manag. 1991, 12, 68-72. [CrossRef]

68. Court, B.; Lupton, R.A. Customer portfolio development: Modeling destination adopters, inactives, and rejecters. J. Travel Res. 1997, 36, 35-43. [CrossRef]

69. Echtner, C.M.; Ritchie, J.B. The meaning and measurement of destination image. J. Tour. Stud. 1991, 2, 2-12.

70. Gartner, W.C.; Shen, J. The impact of Tiananmen Square on China's tourism image. J. Travel Res. 1992, 30, 47-52. [CrossRef]

71. Deng, J.; King, B.; Bauer, T. Evaluating natural attractions for tourism. Ann. Tour. Res. 2020, 29, 422-438. [CrossRef]

72. Tilikidou, I. The effects of knowledge and attitudes upon Greeks' pro-environmental purchasing behaviour. Corp. Soc. Responsib. Environ. Manag. 2007, 14, 121-134. [CrossRef]

73. Webb, D.J.; Mohr, L.A.; Harris, K.E. A re-examination of socially responsible consumption and its measurement. J. Bus. Res. 2008, 61, 91-98. [CrossRef]

74. Baloglu, S.; Mangaloglu, M. Tourism destination images of Turkey, Egypt, Greece, and Italy as perceived by US-based tour operators and travel agents. Tour. Manag. 2001, 22, 1-9. [CrossRef]

75. Smith, M.; Amorim, E.; Soares, C. O turismo acessível como vantagem competitiva: Implicações na imagem do destino turístico. PASOS Rev. Tur. Patrim. Cult. 2013, 11, 97-103. [CrossRef]

76. Gallarza, M.G.; Saura, I.G. Value dimensions, perceived value, satisfaction and loyalty: An investigation of university students' travel. Tour. Manag. 2006, 27, 437-452. [CrossRef]

77. Allameh, S.M.; Pool, J.; Jaberi, A.; Salehzadeh, R.; Asadi, H. Factors influencing sport tourists' revisit intentions: The role and effect of destination image, perceived quality, perceived value and satisfaction. Asia Pac. J. Mark. Logist. 2015, 27, 191-207. [CrossRef]

78. Lee, B.; Lee, C.K.; Lee, J. Dynamic nature of destination image and influence of tourist overall satisfaction on image modification. J. Travel Res. 2014, 53, 239-251. [CrossRef]

79. Prayag, G.; Ryan, C. Antecedents of tourists' loyalty to Mauritius: The role and influence of destination image, place attachment, personal involvement, and satisfaction. J. Travel Res. 2012, 51, 342-356. [CrossRef]

80. Puh, B. Destination image and tourism satisfaction: The case of a Mediterranean destination. Mediterr. J. Soc. Sci. 2014, 5, 538-544. [CrossRef]

81. Veasna, S.; Wu, W.Y.; Huang, C.H. The impact of destination source credibility on destination satisfaction: The mediating effects of destination attachment and destination image. Tour. Manag. 2013, 36, 511-526. [CrossRef]

82. Barroso Castro, C.; Martín Armario, E.; Martín Ruiz, D. The influence of market heterogeneity on the relationship between a destination's image and tourists' future behaviour. Tour. Manag. 2007, 28, 175-187. [CrossRef]

83. Assaker, G.; Hallak, R. Moderating effects of tourists' novelty-seeking tendencies on destination image, visitor satisfaction, and short-and long-term revisit intentions. J. Travel Res. 2013, 52, 600-613. [CrossRef] 
84. Assaker, G.; Vinzi, V.E.; O'Connor, P. Examining the effect of novelty seeking, satisfaction, and destination image on tourists' return pattern: A two factor, non-linear latent growth model. Tour. Manag. 2011, 32, 890-901. [CrossRef]

85. Prayag, G. Tourists' evaluations of destination image, satisfaction, and future behavioral intentions-The case of Mauritius. J. Travel Tour. Mark. 2009, 26, 836-853. [CrossRef]

86. Song, Z.; Su, X.; Li, L. The indirect effects of destination image on destination loyalty intention through tourist satisfaction and perceived value: The bootstrap approach. J. Travel Tour. Mark. 2013, 30, 386-409. [CrossRef]

87. Kim, J.H. The impact of memorable tourism experiences on loyalty behaviors: The mediating effects of destination image and satisfaction. J. Travel Res. 2018, 57, 856-870. [CrossRef]

88. Meng, S.M.; Liang, G.S.; Yang, S.H. The relationships of cruise image, perceived value, satisfaction, and post-purchase beha vioral intention on Taiwanese tourists. Afr. J. Bus. Manag. 2011, 1, 19-29. [CrossRef]

89. Sanz-Blas, S.; Buzova, D.; Carvajal-Trujillo, E. Familiarity and visit characteristics as determinants of tourists' experience at a cruise destination. Tour. Manag. Perspect. 2019, 30, 1-10. [CrossRef]

90. Hung, K.; Petrick, J.F. Why do you cruise? Exploring the motivations for taking cruise holidays, and the construction of a cruising motivation scale. Tour. Manag. 2011, 32, 386-393. [CrossRef]

91. Jin, N.P.; Lee, H.; Lee, S. Event quality, perceived value, destination image, and behavioral intention of sports events: The case of the IAAF World Championship, Daegu, 2011. Asia Pac. J. Tour. Res. 2011, 18, 849-864. [CrossRef]

92. Chen, C.C.; Lai, Y.H.R.; Petrick, J.F.; Lin, Y.H. Tourism between divided nations: An examination of stereotyping on destination image. Tour. Manag. 2016, 55, 25-36. [CrossRef]

93. Cheng, T.M.; Wu, H.C. How do environmental knowledge, environmental sensitivity, and place attachment affect environmentally responsible behavior? An integrated approach for sustainable island tourism. J. Sustain. Tour. 2015, 23, 557-576. [CrossRef]

94. Paraskevaidis, P.; Andreotis, K. Values of souvenirs as commodities. Tour. Manag. 2015, 48, 1-10. [CrossRef]

95. Ortegón-Cortázar, L.; Royo-Vela, M. Nature in malls: Effects of a natural environment on the cognitive image, emotional response, and behaviors of visitors. Eur. Res. Manag. Bus. Econ. 2019, 25, 38-47. [CrossRef]

96. Sanz-Blas, S.; Carvajal-Trujillo, E. Cruise passengers' experiences in a Mediterranean port of call. The case study of Valencia. Ocean Coast. Manag. 2014, 102, 307-316. [CrossRef]

97. Lee, H.E. Does a server's attentiveness matter? Understanding intercultural service encounters in restaurants. Int. J. Hosp. Manag. 2015, 50, 134-144. [CrossRef]

98. Zhang, X. Study on the influence of ecotourism environmental image on leisure experience and tourism satisfaction. Ekoloji 2019, $28,1251-1257$.

99. Zaheer, N.; Trkman, P. An information sharing theory perspective on willingness to share information in supply chains. Int. J. Logist. Manag. 2017, 28, 417-443. [CrossRef]

100. Coudounaris, D.N.; Sthapit, E. Antecedents of memorable tourism experience related to behavioral intentions. Psychol. Mark. 2017, 34, 1084-1093. [CrossRef]

101. Mak, A.H.N. Online destination image: Comparing national tourism organisation's and tourists' perspectives. Tour. Manag. 2017, 60, 280-297. [CrossRef]

102. Lee, J.A. A study on the effects of leisure experience, leisure negotiation, perceived value \& behavioral intention in rural areas. $J$. Hotel Res. 2016, 15, 247-267.

103. Pizam, A.; Ellis, T. Customer satisfaction and its measurement in hospitality enterprises. Int. J. Contemp. Hosp. Manag. 1999, 326-339. [CrossRef]

104. Lounsbury, J.W.; Hoopes, L.L. An investigation of factors associated with vacation satisfaction. J. Leis. Res. 1985, 17, 1-13. [CrossRef]

105. Simarmata, J.; Yuliantini, Y.; Keke, Y. The Influence of Travel Agent, Infrastructure and Accommodation on Tourist Satisfaction. In Proceedings of the International Conference on Tourism, Gastronomy, and Tourist Destination (ICTGTD 2016), Djakarta, Indonesia, 14-15 November 2016; Advances in Economics, Business and Management Research; Atlantis Press: Paris, France, 2016; Available online: https: / / www.atlantis-press.com/proceedings/ictgtd-16 (accessed on 24 May 2021).

106. Yoon, Y.; Uysal, M. An examination of the effects of motivation and satisfaction on destination loyalty: A structural model. Tour. Manag. 2005, 26, 45-56. [CrossRef]

107. Nasir, M.; Mohamad, M.; Ghani, N.; Afthanorhan, A. Testing mediation roles of place attachment and tourist satisfaction on destination attractiveness and destination loyalty relationship using phantom approach. Manag. Sci. Lett. 2020, 10, 443-454. [CrossRef]

108. Zeithaml, V.A. Consumer perceptions of price, quality and value: A means-end model and synthesis of evidence. J. Mark. 1988, 52, 2-22. [CrossRef]

109. Lovelock, C.H. Service Marketing; Prentice Hall International: Hoboken, NJ, USA, 2000.

110. Parasuraman, A.; Grewal, D. The impact of technology on the quality-value-loyalty chain: A research agenda. J. Acad. Mark. Sci. 2000, 28, 168-174. [CrossRef]

111. Babin, B.J.; Kim, K. International students' travel behavior: A model of the travel-related consumer/dissatisfaction process. J. Travel Tour. Mark. 2001, 10, 93-106. [CrossRef]

112. Kashyap, R.; Bojanic, D.C. A structural analysis of value, quality, and price perceptions of business and leisure travelers. J. Travel Res. 2000, 39, 45-51. [CrossRef] 
113. McDougall, G.H.; Levesque, T. Customer satisfaction with services: Putting perceived value into the equation. J. Serv. Mark. 2000, 14, 392-410. [CrossRef]

114. Murphy, P.; Pritchard, M.P.; Smith, B. The destination product and its impact on traveller perceptions. Tour. Manag. 2000, 21, 43-52. [CrossRef]

115. Oh, H. Price fairness and its asymmetric effects on overall price, quality, and value judgments: The case of an upscale hotel. Tour. Manag. 2003, 24, 387-399. [CrossRef]

116. Petrick, J.F.; Backman, S.J. An examination of the construct of perceived value for the prediction of golf travelers' intentions to revisit. J. Travel Res. 2002, 41, 38-45. [CrossRef]

117. Ravald, A.; Grönroos, C. The value concept and relationship marketing. Eur. J. Mark. 1996, 19-30. [CrossRef]

118. Tarn, J.L. The effects of service quality, perceived value and customer satisfaction on behavioral intentions. J. Hosp. Leis. Mark. 1999, 6, 31-43. [CrossRef]

119. Chen, C.F.; Chen, F.S. Experience quality, perceived value, satisfaction and behavioral intentions for heritage tourists. Tour. Manag. 2010, 31, 29-35. [CrossRef]

120. Lee, S.; Jeon, S.; Kim, D. The impact of tour quality and tourist satisfaction on tourist loyalty: The case of Chinese tourists in Korea. Tour. Manag. 2011, 32, 1115-1124. [CrossRef]

121. Bajs, I. Tourist perceived value, relationship to satisfaction and behavioural intentions: The example of the Croatian tourist destination Dubrovnik. J. Travel Res. 2013, 54, 1-13. [CrossRef]

122. Petrick, J.F. Segmenting cruise passengers with price sensitivity. Tour. Manag. 2005, 26, 753-762. [CrossRef]

123. Quintal, V.A.; Polczynski, A. Factors influencing tourists' revisit intentions. Asia Pac. J. Mark. Logist. 2010, 554-578. [CrossRef]

124. Forgas-Coll, S.; Palau-Saumell, R.; Sanchez-Garcia, J.; Garrigos-Simon, F.J. Comparative analysis of american and spanish cruise passengers' behavioral intentions. RAE Rev. Adm. Empresas. 2016, 56, 87-100. [CrossRef]

125. Lobo, A.C. Enhancing luxury cruise liner operators' competitive advantage: A study aimed at improving customer loyalty and future patronage. J. Travel Tour. Mark. 2008, 25, 1-12. [CrossRef]

126. Taplin, R.H. The influence of competition on visitor satisfaction and loyalty. Tour. Manag. 2013, 36, 238-246. [CrossRef]

127. Israeli, A.A. A preliminary investigation of the importance of site accessibility factors for disabled tourists. J. Travel Res. 2002, 41, 101-104. [CrossRef]

128. Li, Y.; Hu, C.; Huang, C.; Duan, L. The concept of smart tourism in the context of tourism information services. Tour. Manag. 2017, 58, 293-300. [CrossRef]

129. Wisker, Z.L.; Kadirov, D.; Nizar, J. Marketing a destination brand image to Muslim tourists: Does accessibility to cultural needs matter in developing brand loyalty? J. Hosp. Tour. Res. 2020. [CrossRef]

130. Wang, C.Y.; Hsu, M.K. The relationships of destination image, satisfaction, and behavioral intentions: An integrated model. J. Travel Tour. Mark. 2010, 27, 829-843. [CrossRef]

131. Lee, K.Y.; Lee, C.K.; Lee, S.K.; Babin, B.J. Festivalscapes and patrons' emotions, satisfaction, and loyalty. J. Bus. Res. 2008, 61, 56-64. [CrossRef]

132. Zeithaml, V.A.; Berry, L.L.; Parasuraman, A. The behavioral consequences of service quality. J. Mark. 1996, 60, 31-46. [CrossRef]

133. Brida, J.G.; Coletti, P. Tourists' intention of returning to a visited destination: Cruise ship passengers in Cartagena de Indias, Colombia. Tour. Mar. Environ. 2012, 8, 127-143. [CrossRef]

134. Brida, J.G.; Pulina, M.; Riaño, E.; Zapata-Aguirre, S. Cruise visitors' intention to return as land tourists and to recommend a visited destination. Anatolia 2012, 23, 395-412. [CrossRef]

135. Satta, G.; Parola, F.; Penco, L.; Persico, L. Word of mouth and satisfaction in cruise port destinations. Tour. Geogr. 2015, 17, 54-75. [CrossRef]

136. Instituto Nacional de Estadística (National Statistics Institute of Spain). Cifras Oficiales de Población Resultantes de la Revisión del Padrón Municipal a 1 de Enero. Resumen por Capitales de Provincia. 2019. Available online: https://www.ine.es/jaxiT3 /Tabla.htm? $\mathrm{t}=2911 \& \mathrm{~L}=0$ (accessed on 6 June 2020).

137. Sánchez-Teba, E.M.; Benítez-Márquez, M.D.; Romero-Navas, T. Residents' negative perceptions towards tourism, loyalty and happiness: The case of Fuengirola, Spain. Sustainability 2019, 11, 6841. [CrossRef]

138. Puertomalaga.com. Photo (c) Figure 1. Panoramic View of the Port of Malaga (with Authorization from the Port of Malaga). Available online: https:/ / www.puertomalaga.com/wp-content/themes/puerto/images/panoramica-puerto.jpg (accessed on 24 April 2021).

139. Chin, W.W. How to write and report PLS analyses. In Handbook of Partial Least Squares: Concepts, Methods and Applications; Esposito Vinzi, V., Chin, W.W., Henseler, J., Wang, H., Eds.; Springer Handbooks of Computational Statistics Series; Springer: Berlin/Heidelberg, Germany, 2010; Volume II, pp. 655-690.

140. Ringle, C.M.; Wende, S.; Becker, J.M. Software "SmartPLS 3" (Version Professional 3.3.3, Update 2021); Boenningstedt, Germany, 2015. Available online: http:/ / www.smartpls.com (accessed on 24 May 2021).

141. Bloemer, J.; Ruyter, K. On the relationship between store image, store satisfaction and store loyalty. Eur. J. Mark. 1998, 32, 499-513. [CrossRef]

142. Bolton, R.N.; Lemon, K.N. A dynamic model of customers' usage of services: Usage as an antecedent and consequence of satisfaction. J. Mark. Res. 1999, 36, 171-186. [CrossRef] 
143. Antón, C.; Camarero, C.; Laguna-Garcia, M. Towards a new approach of destination loyalty drivers: Satisfaction, visit intensity and tourist motivations. Curr. Issues Tour. 2017, 20, 238-260. [CrossRef]

144. Campo-Martínez, S.; Garau-Vadell, J.B.; Martínez-Ruiz, M.P. Factors influencing repeat visits to a destination: The influence of group composition. Tour. Manag. 2010, 31, 862-870. [CrossRef]

145. Moore, S.A.; Rodger, K.; Taplin, R. Moving beyond visitor satisfaction to loyalty in nature-based tourism: A review and research agenda. Curr. Issues Tour. 2015, 18, 667-683. [CrossRef]

146. Vareiro, L.; Ribeiro, J.C.; Remoaldo, P.C. What influences a tourist to return to a cultural destination? Int. J. Tour. Res. 2019, 21, 280-290. [CrossRef]

147. Hair, J.F., Jr.; Hult, G.T.M.; Ringle, C.M.; Sarstedt, M. A Primer on Partial Least Squares Equation Modeling (PLS-SEM), 2nd ed.; Sage Publication, Inc.: Thousand Oaks, CA, USA, 2017.

148. Benitez, J.; Henseler, J.; Castillo, A.; Schuberth, F. How to perfom and report an impactful analysis using partial least squares: Guidelines for confirmatory and explanatory IS research. Inf. Manag. 2020, 57, 103168. [CrossRef]

149. Dijkstra, T.K.; Henseler, J. Consistent partial least squares path modeling. Manag. Inf. Syst. 2015, 39, 297-316. Available online: https://www.jstor.org/stable/26628355 (accessed on 23 April 2021).

150. Nitzl, C.; Roldan, J.L.; Cepeda, G. Mediation analysis in partial least squares path modeling: Helping researchers discuss more sophisticated models. Ind. Manag. Data Syst. 2016, 116. [CrossRef]

151. Cepeda-Carrion, G.; Cegarra-Navarro, J.G.; Cillo, V. Tips to use partial least squares structural equation modelling (PLS-SEM) in knowledge management. J. Knowl. Manag. 2019, 23, 67-89. [CrossRef]

152. Hair, J.F.; Risher, J.J.; Sarstedt, M.; Ringle, C.M. When to use and how to report the results of PLS-SEM. Eur. Bus. Rev. 2019, 31, 2-24. [CrossRef]

153. Hair, J.F.; Hult, G.T.; Ringle, C.M.; Sarstedt, M.; Castillo-Apraiz, J.; Cepeda Carrion, G.; Roldan, J.L. Manual de Partial Least Squares Structural Equation Modeling (PLS-SEM); Omnia Science Omnia Publisher SL: Barcelona, Spain, 2019.

154. Hair, J.F., Jr.; Sarstedt, J.; Hopkins, L.; Kuppelwieser, V.G. Partial least squares structural equation modeling (PLS-SEM). Eur. Bus. Rev. 2014, 26, 106-121. [CrossRef]

155. Werts, C.E.; Linn, R.L.; Jöreskog, K.G. Intraclass reliability estimates: Testing structural assumptions. Educ. Psychol. Meas. 1974, 34, 25-33. [CrossRef]

156. Nunnally, J.C.; Bernstein, I.H. Psychometric Theory, 3rd ed.; McGraw-Hill, Inc.: New York, NY, USA, 1994.

157. Cronbach, L.J. Coefficient alpha and internal structure of test. Psychometrika 1951, 16, 297-334. [CrossRef]

158. Fornell, C.; Larcker, D.F. Evaluating structural equation models with unobservable variables and measurement error. J. Mark. Res. 1981, 18, 39-50. [CrossRef]

159. Henseler, J.; Ringle, C.R.; Sarstedt, M. A new criterion for assessing discriminant validity in variance-based structural equation modeling. J. Acad. Mark. Sci. 2015, 43, 115-135. [CrossRef]

160. Chin, W.; Cheah, J.H.; Liu, Y.; Ting, H.; Lim, X.J.; Cham, T.H. Demystifying the role of causal-predictive modeling using partial least squares structural equation modeling in information systems research. Ind. Manag. Data Syst. 2020, 120, 2161-2209. [CrossRef]

161. Ali, F.; Rasoolimanesh, S.M.; Sarstedt, M.; Ringle, C.M.; Ryu, K. An assessment of the use of partial least squares structural equation modeling (PLS-SEM) in hospitality research. Int. J. Contemp. Hosp. Manag. 2018, 30, 514-538. [CrossRef]

162. Marin-Garcia, J.; Alfalla-Luque, R. Key issues on partial least squares (PLS) in operations management research: A guide to submissions. J. Ind. Eng. Manag. 2019, 12. [CrossRef]

163. Stone, M. Cross-validatory choice and assessment of statistical predictions (with discussion). J. R. Stat. Soc. Ser. B Stat. Methodol. 1976, 38, 102. [CrossRef]

164. Geisser, S. The predictive sample reuse method with applications. J. Am. Stat. Assoc. 1975, 70, 320-328. [CrossRef]

165. Diamantopoulos, A.; Siguaw, J.A. Formative versus reflective indicators in organizational measure development: A comparison and empirical illustration. Br. J. Manag. 2006, 17, 263-282. [CrossRef]

166. Hair, F.J.; Black, C.W.; Babin, J.B.; Anderson, E.R. Multivariate Data Analysis, 7th ed.; Pearson Education Limited: Essex, UK, 2014.

167. Falk, R.F.; Miller, N.B. A Primer for Soft Modeling; University of Akron Press: Akron, OH, USA, 1992.

168. Cohen, J. Statistical Power Analysis for the Behavioral Sciences; Lawrence Erlbaum: Mahwah, NJ, USA, 1988.

169. Ringle, C.M.; Sarstedt, M.; Mitchell, R.; Gudergan, S.P. Partial least squares structural equation modeling in HRM research. Int. J. Hum. Resour. Manag. 2018, 1-27. [CrossRef]

170. Streukens, S.; Leroi-Werelds, S. Bootstrapping and PLS-SEM: A step-by-step guide to get more out of your bootstrap results. Eur. Manag. J. 2016, 34, 618-632. [CrossRef]

171. Qu, H.; Ping, E.W.Y. A service performance model of Hong Kong cruise travelers' motivation factors and satisfaction. Tour. Manag. 1999, 2, 237-244. [CrossRef] 